\title{
High resolution climate projections to assess the future vulnerability of European urban areas to climatological extreme events
}

\author{
Joachim Fallmann ${ }^{1} \cdot$ Sven Wagner ${ }^{1,2} \cdot$ Stefan Emeis $^{1}$
}

Received: 23 January 2015 / Accepted: 6 October 2015 / Published online: 26 October 2015

(C) The Author(s) 2015. This article is published with open access at Springerlink.com

\begin{abstract}
Results from high resolution 7-km WRF regional climate model (RCM) simulations are used to analyse changes in the occurrence frequencies of heat waves, of precipitation extremes and of the duration of the winter time freezing period for highly populated urban areas in Central Europe. The projected climate change impact is assessed for 11 urban areas based on climate indices for a future period (2021-2050) compared to a reference period (1971-2000) using the IPCC AR4 A1B Scenario as boundary conditions. These climate indices are calculated from daily maximum, minimum and mean temperatures as well as precipitation amounts. By this, the vulnerability of these areas to future climate conditions is to be investigated. The number of heat waves, as well as the number of single hot days, tropical nights and heavy precipitation events is projected to increase in the near future. In addition, the number of frost days is significantly decreased. Probability density functions of monthly mean summer time temperatures show an increase of the 95 th percentile of about $1-3^{\circ} \mathrm{C}$ for the future compared with the reference period. The projected increase of cooling and decrease of heating degree days indicate the possible impact on urban energy consumption under future climate conditions.
\end{abstract}

Joachim Fallmann

joachim.fallmann@kit.edu

1 Institute of Meteorology and Climate Research - Atmospheric Environmental Research (IMK-IFU), Karlsruhe Institute of Technology (KIT), Campus Alpin, Kreuzeckbahnstr. 19, 82467 Garmisch-Partenkirchen, Germany

2 Institute of Geography, University of Augsburg, Alter Postweg 118, 86135 Augsburg, Germany

\section{Introduction}

In 2050, the fraction of global urban population will increase to over $69 \%$ (Europe $82 \%$ ), which means that around 6.3 billion people are expected to live in urban areas (United Nations 2011). The transformation of rural into urban areas is one of the most severe facette of anthropogenic land use change. Presently, only $1.2 \%$ of land surfaces are regarded as urban areas (Shepherd 2005), but cities are the main contributor to global greenhouse gas emissions. With $78 \%$ of the total global carbon emissions, urban systems are to a large extend responsible for global climate change (Grimm et al. 2008). Cities are places of human activity and are therefore particularly vulnerable to climate extremes like heat waves. The overwarming of urban areas due to the urban heat island effect (Oke, 1982b) adds to the general effect of global temperature increase. Meteorological features like humidity, wind speed or radiation as well significantly impact human comfort. From an energetic perspective, a side effect coming along with the excessive warming is an increase of cooling load in summer and a projected decrease of heating load in winter. This aspect can result on the one hand in increased demand of energy and higher emissions in summer, but on the other hand, a positive feedback on wintertime energy consumption and air pollution can be achieved.

In the IPCC AR5 (IPCC 2013), it is concluded that heat waves, or extreme precipitation events, are more likely to occur in the future and a high human contribution to the already observed changes is to be assumed. The results of Poumadere et al. (2005) suggest that climate change could have been responsible for the European Heat Wave 2003. This event developed into the single most catastrophic weather event to have haunted Europe since the beginning of 
weather observations. The EU estimated that more than 70 , 000 people within 12 countries died from heat related illnesses, more than in any single event since World War II. (Stone Jr. 2012).

For future urban planning strategies, it is important to know how urban regions will respond to global temperature change, especially regarding the occurrence frequency of heat waves.

Analysing a large amount of observations for Western European Countries from 1980 to 2005, Della-Marta et al. (2007) found that due to a change in extreme warm daily summer maximum temperature, the length of summer heat waves in Western Europe has doubled and the frequency of hot days has almost tripled within this period.

Results from Meehl and Tebaldi (2004) show that the number and intensity of heat waves are supposed to increase in the second half of the 21 st century. Within that study, it is concluded that the average duration of heat waves for the urban area of Paris ranges from 11.4 to 17 days per year for the time period 2080-2099 compared to 8.4 to 12.7 days with regard to the time period 1961-1990.

An increase of the number and intensity of heat waves and a general trend towards higher temperatures in Europa is stated by several studies (Trusilova et al. 2008; Beniston 2004; Beniston et al. 2007; Beniston 2009).

Over the last decades, the spatial resolution of regional climate models has been continuously increasing. In the course of the PRUDENCE project (Christensen and Christensen 2007), larger ensembles of climate models were carried out for Europe, reaching resolutions of about $50 \mathrm{~km}$. Further studies were performed, ranging from $25 \mathrm{~km}$ with regard to the ENSEMBLES project (Hewitt 2004) to $18 \mathrm{~km}$ in the so-called consortium simulations (Feldmann et al. 2008).

High resolution RCMs are needed for climate impact studies for urban areas. In particular, the exceedance of threshold values regarding maximum temperature or precipitation is of great interest in order to relate climate change impacts to urban population. This study uses results from an existing $7 \mathrm{~km}$ WRF RCM as described in Berg et al. (2013) and Wagner et al. (2013), in order to calculate climate indicators for different urban areas in Europe. Except for single event studies (e.g. Borge et al. 2008; Salathe et al. 2010, Schwitalla et al. 2011), only a few climatological studies using WRF for a European domain and to the authors knowledge, it is the first study existing which discusses climatic extreme events for selected urban areas over parts of Europe. In contrast to selected regional case studies, this study benefits from consistent climate boundary conditions which in turn allows for a European wide analysis and a high degree of comparability between the different urban areas and regional climate change impacts. Climate change indicators which are directly related to human health are illustrated by the number of hot days, duration and occurrence frequencies of future heat waves and number of tropical nights. An aspect which is affecting urban environments in general is the number of heavy precipitation days and the number of frost days. Considering the future energy consumption of urban areas, the number of heating and cooling degree days is included in the analysis. The study combines a spatial and a local analysis of projected climate change impacts based on climate indices for the period 2021-2050 compared to 1971-2000. The spatial analysis regards the whole model domain, whereas the regional analysis presents projected changes for 11 major urban areas. Evaluation with observation data supports the reliability of the regional climate model and probability density functions (PDFs) of temperature give information about future trends in the 95th percentile.

The data and methods which have been used are presented in Chapter 2, which also includes a brief description of the climate indices and their calculation. An evaluation of the high resolution RCM simulations for urban areas is shown in Chapter 3.1, followed by a detailed presentation and discussion of the spatial and regional analysis in Chapter 3.2 and 3.3, respectively. The paper closes with a summary and conclusion in Chapter 4.

\section{Data and methods}

To account for extreme events, different climate indicators are calculated from the model output and spatially displayed for the whole domain and along west-east and south-north transects.

The number of tropical nights, heat waves, heavy precipitation events and frost days are presented for the future 30year time period on the basis of relative changes compared to the reference case. The projected development of heating and cooling degree days gives information about the future energy consumption in urban areas.

The climate indices are calculated from WRF output fields generated in the course of the regional climate ensemble modelling study presented in Berg et al. (2013) and Wagner et al. (2013). The regional climate simulations were performed with the non-hydrostatic Weather Research and Forecasting (WRF) model using the Advanced Research WRF-ARW dynamics solver version 3.1.1 (Skamarock et al., 2008). The IPCC AR4 simulations with the ECHAM5/MPIOM model system at T63 resolution (Roeckner et al. 2003) served as GCM. The WRF simulations followed a double one-way nest procedure in Lambert conformal map projection with the coarse nest over all of Europe $(125 \times 117$ grid points $)$ at $42 \mathrm{~km}$ resolution and the fine nest covering Germany and its neighbouring countries $(175 \times 175$ grid points $)$ at $7 \mathrm{~km}$ resolution. The model used 40 vertical levels for both nests. For the simulations, the following main physical options were selected: the WRF Single-Moment 5-class scheme (WSM5) 
microphysical parameterization (Hong et al. 2004; Hong and Lim 2006), the modified version of the Kain-Fritsch scheme (Kain 2004) for cumulus parameterization, the Noah land surface model (Chen and Dudhia 2001), the Yonsei University (YSU) parameterization (Hong et al. 2006) for the planetary boundary layer, the MM5-Dudhia SW scheme (Dudhia 1989) and the Rapid Radiative Transfer Model (RRTM) longwave radiation scheme (Mlawer et al. 1997). For more details on the WRF setup and the performance for temperature and precipitation in comparison to other RCMs, we refer to Berg et al. (2013).

Taking the IPCC AR4 A1B Scenario (Solomon 2007) as boundary conditions, climate projections for the time period 2021-2050 were carried out and trends calculated to be compared with the reference period 1971-2000.

The fine model domain covers an area between 1.5 to $17.5^{\circ}$ $\mathrm{E}$ and 44.5 to $54.5^{\circ} \mathrm{N}$. The selection of the urban areas (Table 1) is based on their reasonable size and their regional representativeness as a major urban agglomeration in the region.

The cities are equally distributed throughout the model domain (Fig. 1). All maps presented in the following are projected on a decimal LAT/LON grid with WGS 84 projection for Germany Zone $32 \mathrm{~N}$.

USGS classified land use data (USGS 2006) is used to account for land use information. In the RCM run, an urban area is defined via a bulk approach (Liu et al. 2006), where a predefined roughness length of $0.8 \mathrm{~m}$ represents turbulence and drag due to buildings, an albedo of 0.15 accounts for radiative properties of urban canyons and averaged volumetric heat capacities $\left(3.0 \mathrm{~J} \mathrm{~m}^{-3} \mathrm{~K}^{-1}\right)$ and soil thermal conductivities $\left(2.24 \mathrm{~W} \mathrm{~m}^{-1} \mathrm{~K}^{-1}\right)$ characterize heat transfer in building fabrics.

Meteorological variables are extracted from WRF simulations on a daily basis for a reference (1971-2000) and a near future (2021-2050) time period, with the model domain covering Central Europe. Although climate trends would be more pronounced by the end of the 21 st century, the period $2021-$ 2050 is chosen, because it is related to a typical time frame of current urban planning strategies.

Over 262,500 time steps of hourly model output for $2 \mathrm{~m}$ temperature and accumulated daily precipitation are analysed to compute daily mean, maximum and minimum trends for summer (JJA) and winter (DJF) periods. Based on these variables, climate indices for major urban agglomerations in Europe (Table 1) are calculated from the past and future 30year time period.

Features that significantly affect human health, i.e. hot days and unusually high night time temperatures (tropical nights), are analysed in particular. Associated with these effects is the development of heavy precipitation events where daily sums exceed a certain threshold, in this case, $20 \mathrm{~mm}$. The number of frost days with daily minimum temperatures below $0{ }^{\circ} \mathrm{C}$ has
Table 1 Urban areas selected for the study, arranged according to their population number, city size and population density (Brinkhoff 2013)

\begin{tabular}{llll}
\hline City & Population & $\begin{array}{l}\text { Size } \\
\left(\mathrm{km}^{2}\right)\end{array}$ & $\begin{array}{l}\text { Density } \\
\left(\text { Inhabitants } / \mathrm{km}^{2}\right)\end{array}$ \\
\hline Berlin & $3,415,091$ & 892 & 3829 \\
Paris & $2,273,305$ & 105 & 21,651 \\
Vienna & $1,763,654$ & 415 & 4250 \\
Hamburg & $1,751,780$ & 755 & 2315 \\
Munich & $1,402,455$ & 310 & 4524 \\
Prague & $1,243,201$ & 496 & 2527 \\
Cologne & $1,027,679$ & 405 & 2537 \\
Stuttgart & 602,877 & 207 & 2912 \\
Zurich & 400,028 & 92 & 4348 \\
Ljubljana & 278,638 & 275 & 1013 \\
Modena & 179,353 & 182 & 985 \\
\hline
\end{tabular}

no direct health impact to local inhabitants but is relevant for the energy consumption in urban areas. Each climate index refers to a threshold which is defined by the European Climate Assessment \& Dataset project ECA\&D (http://eca.knmi.nl/). Each ECA\&D index which is calculated from the RCM hourly model output using CDO (climate data operator) tools (Mueller and Schulzweida 2010) and by this follows a uniform standard. ECA\&D climate indicators which are presented in the following are in accordance with the thresholds recommended by the World Meteorological Organization (WMO).

\subsection{Calculation of climate indicators}

\subsubsection{Number of hot days}

The number of days per year, where daily maximum temperatures exceed the threshold of $30^{\circ} \mathrm{C}$ is calculated for the future time period and compared to the reference case with regard to the whole domain. Absolute and relative changes are to be analysed.

\subsubsection{Number of heat waves}

A heat wave can be defined by a $5{ }^{\circ} \mathrm{C}$ temperature exceedance on more than 5 consecutive days compared to a 30 -year reference period. In Europe, definitions of threshold temperatures differ regionally (Frich et al. 2002). In Germany, daily maximum temperatures have to be higher than $30{ }^{\circ} \mathrm{C}$ on at least 5 days for being considered as heat wave (Tinz et al. 2008). This criterion is used as reference in this paper.

The number of periods per year, where the threshold temperature of $30^{\circ} \mathrm{C}$ is reached or exceeded on more than a defined number of consecutive days, is calculated for each 
Fig. 1 WRF nested domain with 7-km horizontal resolution, showing USGS, 2006 classified land use, projected on a LAT/ LON grid with the coordinate system WGS 84 Zone $32 \mathrm{~N}$. The urban areas of interest are marked

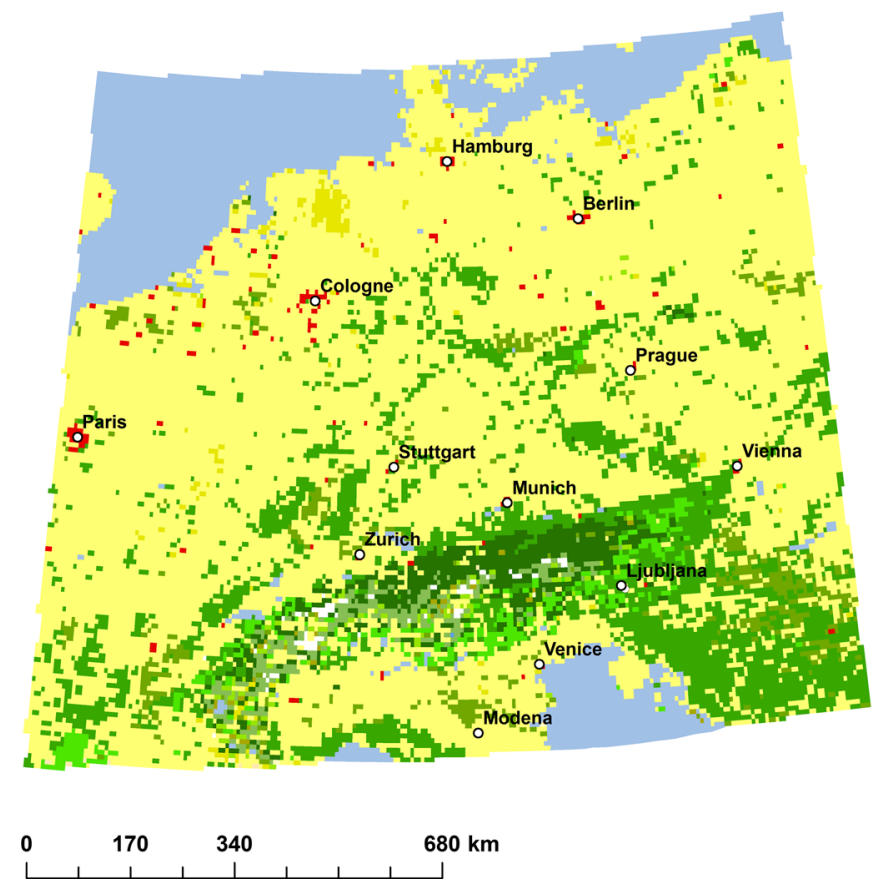

Land use

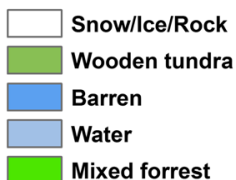

Evergreen needleleaf forest Deciduous broadleaf forest Savanna

Mixed Shrubland/grassland Shrubland Grassland Cropland/woodland mosaic Cropland/grassland mosaic Irrigated cropland and pasture Dry cropland and pasture Urban grid cell which represents one of the 11 cities mentioned in Table 1 . For this purpose, every day within the 30 -year time frame where the maximum temperature exceeds the threshold of $30^{\circ} \mathrm{C}$ is set to 1 - the condition for being classified as 'hot day' is true. Values which fail to correspond to this condition are set to zero. In the following, a mask is applied, which counts the number of periods with the most 'hot days' in a row. Afterwards, the second longest time period is figured out and the number of occurrences are counted. This procedure is applied until the number of 5 consecutive days is reached. A duplication of days is not allowed in the counting. Here, three categories of heat waves can be defined and used for further classifications. A series of 5 and 6 consecutive days is classified as 'moderate' heat waves, 7 to 9 days as 'strong' heat waves and 10 days or more are defined as 'severe' heat waves. By dividing the absolute number of each class by 30 years, the annual average number of heat waves can be calculated for both time periods.

\subsubsection{Tropical nights}

The number of days where the daily minimum temperature is above the threshold of $20^{\circ} \mathrm{C}$ is calculated. To receive annual averages, the total number has to be divided by 30 years. The difference between the future and past period indicates the climate signal.

\subsubsection{Heavy precipitation days}

According to the WMO, heavy precipitation events are defined as daily accumulated precipitation amounts exceeding
$20 \mathrm{~mm}$. In the following, only these events are counted which fall between the summer months (JJA).

The number of days where the amount of daily precipitation sum is at least $20 \mathrm{~mm}$ is calculated, and relative annual trends are presented. The difference between the future and past period indicates the climate signal.

\subsubsection{Frost days}

This is the number of days, where the daily minimum temperature is less than $0{ }^{\circ} \mathrm{C}$. The accumulated number of days for the 30 -year periods is again divided by the number of years, to obtain annual averages for both time periods. Relative changes are analysed comparing future period and reference case.

\subsubsection{Heating and cooling degree days}

Heating and cooling degree days are quantitative indices to assess the effect of ambient temperature on the demand of energy needed for heating and cooling of residential-and commercial buildings to maintain thermal comfort in building interiors. Counted is the number of days, where daily mean temperature exceeds or falls below a predefined threshold which requires air conditioning or heating, respectively. It has to be pointed out, however, that this indicator strongly depends on the human condition and on factors such as buildings isolation and therefore can vary by city or country. This index cannot be directly equated to the indices discussed before, but still it does reveal one of the expected impacts of climate change on urban environments. Recent studies (e.g. 
Erhardt 2015; OrtizBevia et al. 2012) support the importance of including these indices in climate impact studies.

Based on daily mean temperatures, heating degree days (HDD) account for the number of days were daily mean temperatures fall below $15{ }^{\circ} \mathrm{C}$. It is assumed that at this threshold, it is necessary to regularly heat the building interiors, especially during night-time with values dropping below $10^{\circ} \mathrm{C}$. With daily mean temperatures exceeding $20^{\circ} \mathrm{C}$, it is assumed that buildings have to be air conditioned. The number of days where this threshold is exceeded with regard to daily mean temperature is referred to cooling degree days (CDD) (CDO 2014). This study tries to investigate the overall effect of climate change on both indices by comparing the relative trends for the European domain and for selected urban areas.

\subsubsection{Probability density functions (PDF)}

To statistically describe the climate change signal for single urban areas, probability density functions are calculated for mean $2 \mathrm{~m}$ air temperatures for the periods 1971-2000 and 2021-2050, whilst the 95th percentiles are compared. The modified shape of the future PDF's and, additionally, the shift of the 95th percentile to higher values serves as an indicator for the temperature change in urban areas. To estimate the statistical significance of the RCM runs, student's $t$ tests are performed regarding the $95 \%$ confidence interval.

\section{Results and discussion}

In order to analyse the spatial variability of model biases with regard to temperature and precipitation, the RCM run for the period 1971-2000 is compared with E-OBS data (Haylock 2008). Mean biases of temperature and monthly precipitation sums are calculated for each selected urban area as well.

Accordingly, climate indices are calculated on the basis of $2 \mathrm{~m}$ temperature fields as well as daily precipitation amounts, extracted from past (1971-2000) and future (2021-2050) $\mathrm{RCM}$ runs. Climate trends are to be analysed with regard to heat waves, tropical nights, heavy precipitation events, frost days as well as heating and cooling degree days. The results are presented for the whole domain as well as for single urban areas. Further, probability density functions of monthly mean temperature are shown for selected urban areas.

\subsection{Evaluation of temperature and precipitation with E-OBS data}

For the evaluation of simulated temperature and precipitation, an adapted version of the E-OBS dataset (Haylock et al. 2008) is used. Due to temperature being a temporally and spatially continuous variable, the originally coarse resolution E-OBS data (25 km at a regular grid) was downscaled to $7 \mathrm{~km}$ (Berg et al. 2013). For temperature, a constant lapse rate of $6.5 \mathrm{~K} / \mathrm{km}$ was multiplied by the elevation difference between the two data sets. For precipitation, the E-OBS data set was remapped such that the precipitation amounts are conserved. Figure 2 shows the spatial distribution of temperature and precipitation bias with regard to the 30 -year mean value. Blue colour patterns indicate an underestimation, red colours an overestimation compared to the observations. With regard to precipitation, the colouring is reversed.

With more than $2{ }^{\circ} \mathrm{C}$, the South Eastern part of the model domain shows the largest warm temperature bias (Fig. 2a). The positive temperature biases in the south-east, as well as the negative bias in the alpine region, are carried over from the general circulation model GCM (Berg et al. 2013). WRF tends to reduce the cold bias from the driving GCM in Northern and Western Europe. In the region of the Mediterranean and southeast Europe, however, it amplifies the warm bias. The regions with the most robust model results are to be found in the northern part of Germany with almost no bias. According to precipitation (Fig. 2b), the model largely shows an overestimation. Highest positive biases up to $75 \mathrm{~mm}$ per month can be found in the alpine and mountainous regions in general. Some parts in the South East show a negative precipitation bias. For precipitation, the bias from the GCM is carried over. In mountainous regions, the simulation, observation and spatial interpolation of precipitation are additionally very challenging and often associated with larger errors due to topographic effects.

Table 2 presents the evaluation for selected urban areas as presented in Table 1. With regard to the model bias, the discussion above indicates regions where the RCM results are more robust and regions which are afflicted with higher uncertainties.

Except for Hamburg, WRF shows a slight overestimation of mean temperature between $0.1{ }^{\circ} \mathrm{C}$ (Paris, Modena) and $1.9^{\circ} \mathrm{C}$ (Munich) (Table 2). Ljubljana strikes out here with the mean bias reaching $3.2^{\circ} \mathrm{C}$. The model shows a significant warm bias. This effect might be caused by the comparably small size of the urban area and its location in complex terrain, whose effect on local climatology is not accurately accounted for at a resolution of $7 \mathrm{~km}$. Analysing the winter month (DJF) only, the mean bias can be reduced for all urban areas. For the urban areas of Berlin, Modena and Prag, the warm bias is turned into a cold bias compared to the full modelling periods as well as to summer month (JJA) only. Referring to Table 2, climate indices including winter months (number of frost days, heating degree days) tend to be more robust than summer time indices such as heat waves, hot days and cooling degree days.

With regard to Fig. 2b, monthly precipitation sums can be evaluated for the selected urban areas as well (Table 3).

In average, WRF overestimates precipitation fields of the E-OBS data by $17 \mathrm{~mm}$. The largest relative bias is to be found for Berlin (+35\%). The urban area of Ljubljana, however, shows a negative bias. 


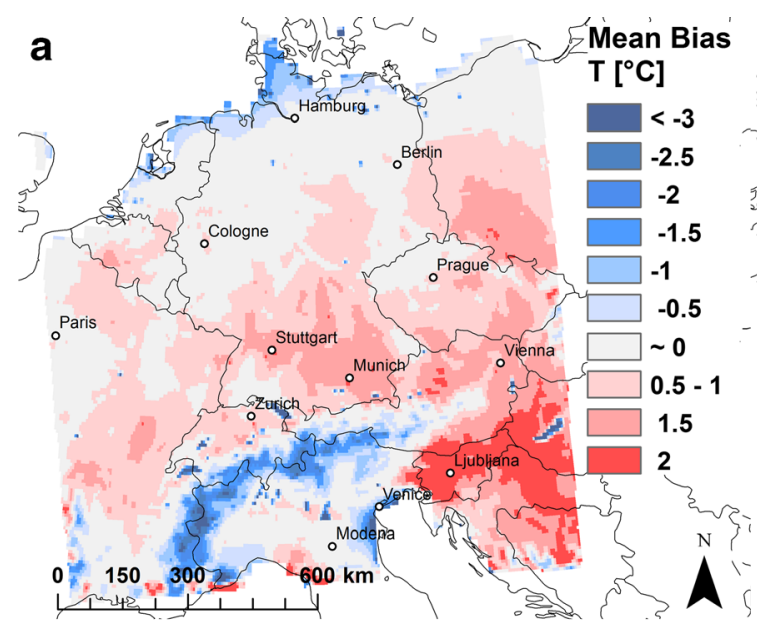

Fig. 2 Mean bias between E-OBS dataset (Haylock 2008) and WRF 7$\mathrm{km}$ RCM for mean temperature (JJA) (a) and averaged summer time (JJA) mean precipitation sum (b) for the 7-km RCM domain with blue

With regard to Table 3, a significant decrease of the mean bias can be observed for summer precipitation (JJA) only. Here, the urban area of Zurich shows the highest decrease of mean bias from 23 to $5 \mathrm{~mm}$. In average, the mean bias averaged over all cities is decreased by a factor of two from 18 to $9 \mathrm{~mm}$. The urban area of Ljubljana, however, shows an underestimation.

Table 3 supports the findings of previous studies (Hofstra el al. 2010; Boberg et al. 2010) indicating a general overestimation compared to the E-OBS precipitation fields. This aspect has to be considered when comparing the modelled and observed monthly mean precipitation sums for selected urban grid cells.

\subsection{Spatial results}

\subsubsection{Hot days}

The spatial variability of the number of hot days within the model domain is presented in Fig. 3 on the basis of absolute

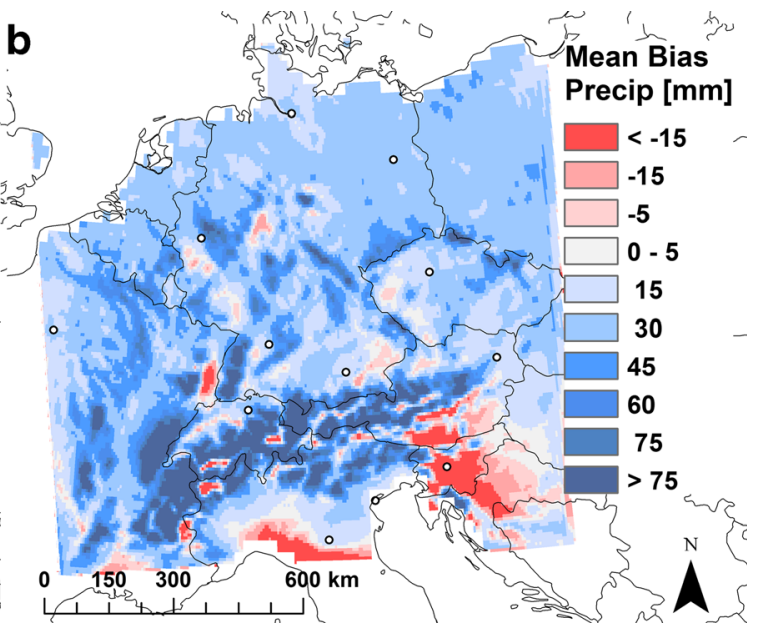

colour patterns indicating an under, red colours an overestimation of the observations for temperature and the reversed for precipitation

simulated number of hot days per year for both past (19712000) (a) and future (2021-2050) (b) periods as well as absolute (c) and relative changes (d).

Red and orange colours in $3 \mathrm{a}$ and $3 \mathrm{~b}$ indicate the number of hot days, reaching 30 days or more. These patterns mainly can be found in the southern part of the domain in southern France, the Po-Valley and the countries Slovenia, Hungary, Slovakia and parts of Lower Austria.

With regard to absolute changes in hot days (Fig. 3c), a slightly different pattern is observed. Here, especially, the Po-Valley indicates large absolute changes in the number of hot days. The number of hot days in the eastern part of the domain remains unchanged. A different result is retrieved when comparing relative changes in number of hot days in the future (Fig. 3d). The coast line in the north western part as well as central France and the areas attached to the Alps show significant relative changes although the absolute number is supposed to be rather low. Some areas which have not encountered any threshold exceedance until now are supposed to face this phenomenon in the future. Highly sensitive regions such

Table 2 Mean observed (OBS) (Haylock 2008) and simulated 2-m temperature (WRF) and mean bias between observation and RCM for the reference period 1971-2000. Summer mean (JJA) and winter mean (DJF) are shown separately

\begin{tabular}{lrrrrrrrrrrr}
\hline & Zurich & Cologne & Hamburg & Berlin & Paris & Stuttgart & Modena & Prague & Vienna & Ljubljana & Munich \\
\hline OBS $\left({ }^{\circ} \mathrm{C}\right)$ & 9.0 & 10.5 & 9.3 & 9.6 & 12.0 & 9.3 & 13.9 & 9.9 & 10.4 & 9.4 & 8.6 \\
WRF $\left({ }^{\circ} \mathrm{C}\right)$ & 10.0 & 11.0 & 9.1 & 10.2 & 12.2 & 10.6 & 14.1 & 10.6 & 11.7 & 12.6 & 10.5 \\
Mean bias $\left({ }^{\circ} \mathrm{C}\right)$ & 1.0 & 0.5 & -0.2 & 0.6 & 0.1 & 1.4 & 0.1 & 0.6 & 1.3 & 3.2 & 1.9 \\
JJA_OBS $\left({ }^{\circ} \mathrm{C}\right)$ & 17.1 & 17.9 & 16.9 & 18.1 & 19.2 & 17.6 & 23.6 & 18.8 & 19.5 & 18.2 & 17.0 \\
JJA_WRF $\left({ }^{\circ} \mathrm{C}\right)$ & 18.4 & 18.5 & 16.5 & 19.2 & 19.4 & 19.1 & 25.7 & 20.3 & 22.1 & 23.1 & 19.6 \\
JJA_Mean bias $\left({ }^{\circ} \mathrm{C}\right)$ & 1.3 & 0.6 & -0.5 & 1.1 & 0.2 & 1.4 & 2.1 & 1.6 & 2.5 & 5.0 & 2.6 \\
DJF_OBS $\left({ }^{\circ} \mathrm{C}\right)$ & 1.1 & 3.5 & 2.1 & 1.4 & 5.4 & 1.2 & 4.4 & 1.4 & 1.2 & 0.6 & 0.3 \\
DJF_WRF $\left({ }^{\circ} \mathrm{C}\right)$ & 1.9 & 3.6 & 1.6 & 1.0 & 5.4 & 2.6 & 2.9 & 0.7 & 1.4 & 2.5 & 1.5 \\
DJF_Main bias $\left({ }^{\circ} \mathrm{C}\right)$ & 0.8 & 0.1 & -0.4 & -0.4 & 0.0 & 1.3 & -1.5 & -0.6 & 0.2 & 1.9 & 1.2 \\
\hline
\end{tabular}


Table 3 Mean values of observed (OBS) and simulated (WRF) monthly precipitation sums and averaged monthly precipitation sums considering summer month only (JJA) - for the reference period 1971-2000

\begin{tabular}{|c|c|c|c|c|c|c|c|c|c|c|c|}
\hline & Zurich & Cologne & Hamburg & Berlin & Paris & Stuttgart & Modena & Prague & Vienna & Ljubljana & Munich \\
\hline OBS (mm) & 95 & 65 & 61 & 43 & 51 & 60 & 53 & 37 & 46 & 117 & 84 \\
\hline WRF (mm) & 118 & 80 & 76 & 67 & 73 & 77 & 66 & 52 & 64 & 71 & 98 \\
\hline Mean bias (mm) & 23 & 14 & 15 & 24 & 21 & 17 & 13 & 15 & 18 & -46 & 14 \\
\hline JJA_OBS (mm) & 131 & 76 & 70 & 55 & 49 & 77 & 42 & 59 & 60 & 134 & 123 \\
\hline JJA_WRF (mm) & 136 & 88 & 79 & 71 & 61 & 94 & 47 & 69 & 63 & 71 & 126 \\
\hline JJA_Mean bias (mm) & 5 & 12 & 9 & 16 & 12 & 17 & 4 & 10 & 3 & -63 & 3 \\
\hline
\end{tabular}

as the coast lines and the pre-alpine areas show a high relative increase of days exceeding the $30{ }^{\circ} \mathrm{C}$ limit. In past periods (Fig. 3a), this effect has not been encountered at all for these region, which leads to the fact that only small absolute changes (Fig. 3c) lead to a high relative increase. The entire prealpine region for instance is projected to face between 1 and 2 more hot days per year. These values, however, account for a relative increase of $55 \%$ and more. A similar effect can be seen at the entire coast line of the North Sea for both Great Britain and the European mainland.

The statistical significance of the modelled temperature is analysed by applying a student's $t$ test and plotted within Fig. 3b. Black crosses indicate a failure of the $95 \%$ confidence interval with regard to mean temperature, which is mostly present in the Northern part of Germany.

Figure $3 \mathrm{~d}$ shows a horizontal cross section from west to east, covering a distance of about $1000 \mathrm{~km}$ including the urban areas of Paris, Stuttgart, Munich and Vienna (Fig. 4).

Considering relative changes in hot days (Fig. 4), a westeast trend can be observed with values dropping from about 25 to almost $0 \%$. Slight fluctuations of $\pm 5 \%$ can be observed. The average west-east trend in relative change accounts for about $2.5 \%$ per $100 \mathrm{~km}$. The slight increase between 200 and $450 \mathrm{~km}$, the area east of Stuttgart and the plateau east of Munich represent the complex terrain of the Vosges and the Black Forrest, the Swabian Alb and the Bavarian Forrest respectively. Similar to the pre-alpine regions, these areas are more sensitive to climate change than others.

Both surface and cross-section plots indicate a higher increase of heat waves in the western than in the eastern part of the domain. With an increase of 20 to $25 \%$ compared to the reference case, in particular, the area expanding from Paris to Stuttgart will presumably suffer from more days with elevated summer time temperatures, promoting local heat stress for the urban dwellers. At this point, one has to be aware that especially in the region around Ljubljana, mean biases between model and observation over $3{ }^{\circ} \mathrm{C}$ are to be observed (Fig. 2). This could lead to a misinterpretation of calculated indices.

The colour pattern in Fig. $3 \mathrm{~b}$ is similar to the patterns found by Robine (2008), where satellite observed surface temperatures over Europe for the summer heat wave 2003 have been connected to mortality rates throughout the continent.

\subsubsection{Tropical nights}

Figure 5 illustrates the number of nights, where minimum temperatures do not fall below $20^{\circ} \mathrm{C}$. Absolute numbers of the past (5a) and the future period (5b) are presented here, in addition to absolute (5c) and relative changes ( $5 \mathrm{~d})$.

The spatial patterns of Fig. 5 correspond to Fig. 3 because 'Hot days' regions cannot significantly cool down and high temperatures remain throughout the night. With regard to absolute values, the Po-Valley and some areas in Southern France are assumed to face a high number of tropical nights with occurrences of more than 30 times per year. Absolute trends indicate a negative gradient towards the North.

Relative trends (Fig. 5d) reveal a different picture, which is comparable to Fig. 3d. The areas along the shoreline of the Northern Sea as well as the west and south-west part, the prealpine region and the western coastline of Italy show a relative increase of $55 \%$ and above. In general, a larger climate signal is projected for the number of tropical nights than for the number of hot days and it seems that the effect is extended more from the coast towards the mainland. With more than $45 \%$, the south-western and north-western parts of the domain show the highest relative increase in the number of tropical nights, although especially in the northern part, this number represents only a small absolute value ( $2-4$ days). Within the Po-Valley, there is a large discrepancy between absolute and relative changes. The most prominent changes are projected for the southern part of France, where the number of tropical nights is supposed to double from 7 to 15 days per year. The area of Hamburg, for instance, experiences only four tropical nights per year on average, but an increase of almost $50 \%$ clearly reflects the climate signal. In average, an increase of $30 \%$ is projected for Europe. With regard to Fig. $5 \mathrm{~d}$, a clear trend from west to east can be observed concerning the relative increase of tropical nights which ranges from $40 \%$ in the area of Paris, down to less than $10 \%$ in the vicinity of Vienna. 


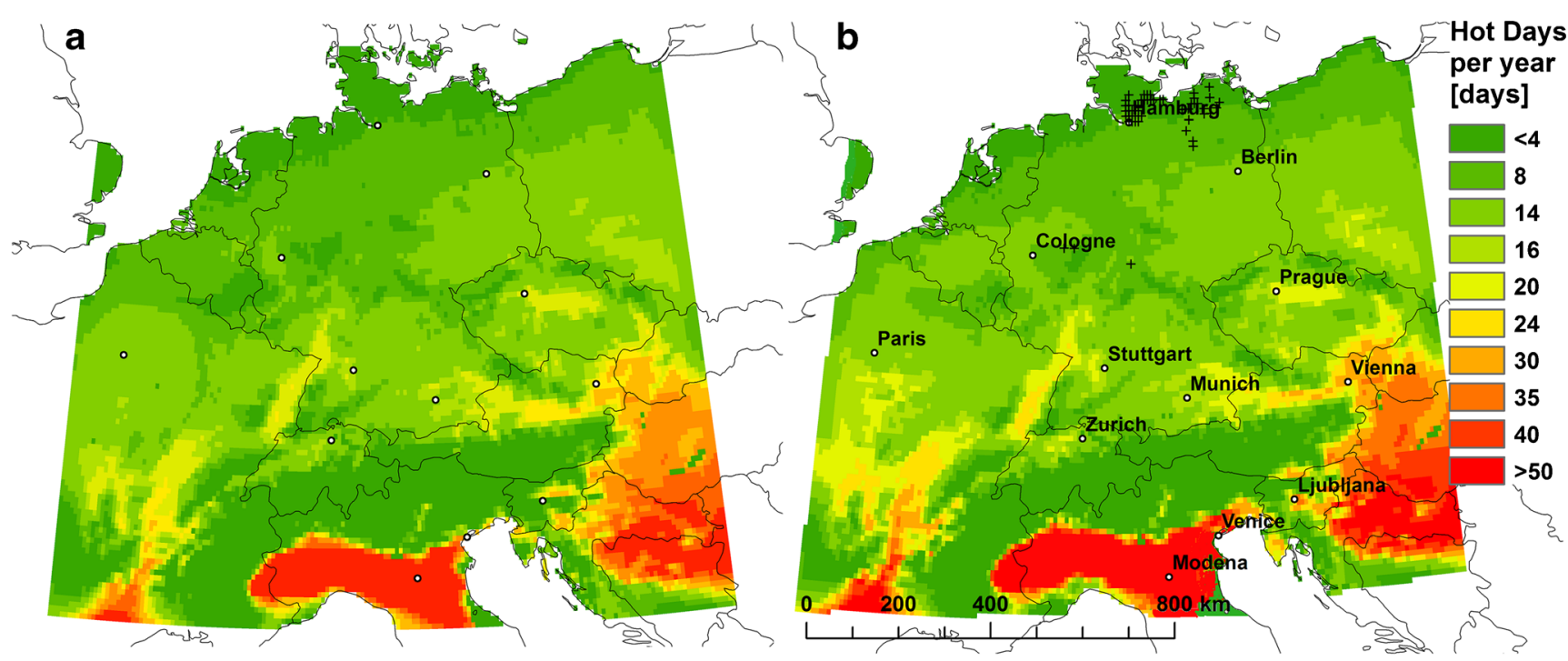

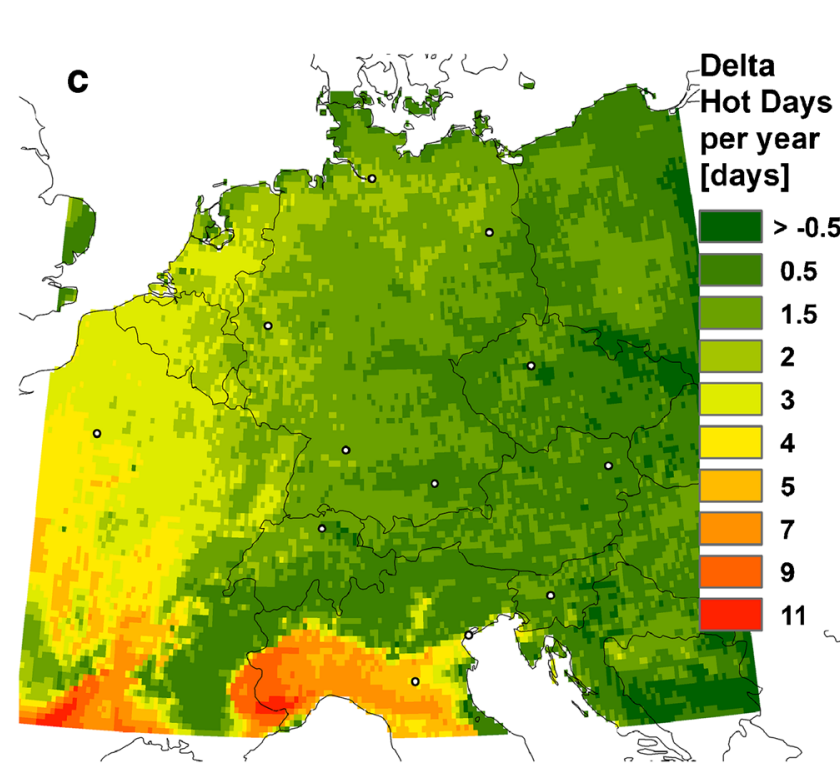

Fig. 3 European domain, showing yearly averages of past (1971-2000) (a) and projected (2021-2050) number of hot days (daily maximum exceed $30^{\circ} \mathrm{C}$ ) (b). The absolute (c) and relative trend (d) compared to the reference period (1971-2000) is presented in the lower part. Black

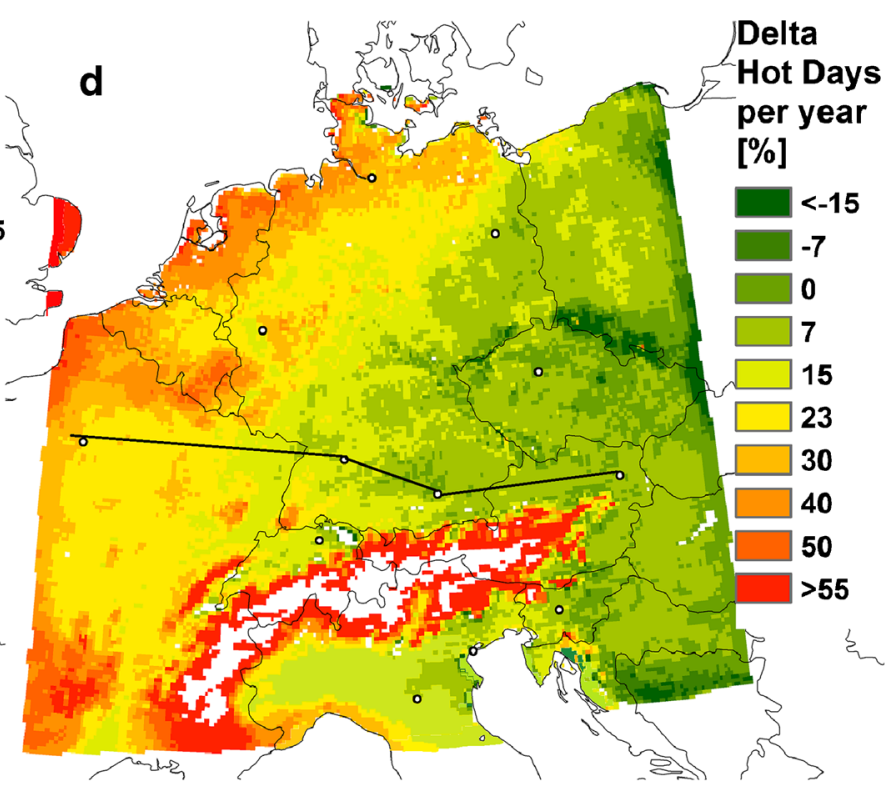

crosses (b) display a failure of the $95 \%$ confidence interval with regard to mean temperature. Cross section for Fig. 3 is indicated as black dotted line in (d). White shading in the area of the Alps denotes no data values due to division by zero

\subsubsection{Heavy precipitation days}

Figure 6 shows the number of heavy precipitation days (HPD) simulated for the past (1971-2000) (6a) and projected for the future period 2021-2050 (6b). Absolute and relative changes compared to the reference period are presented by Fig. 6c, d. In this study, this index is only discussed for the summer months June, July and August (JJA), because in Europe, heavy precipitation events are more likely to occur in the summer months (Frei et al. 2001; Haylock et al. 2006). Second, a significant decrease of the mean bias and the slight increase in correlation are observed for the summer months (JJA) (Table 3).

In general, WRF simulates heavy precipitation days occurring predominantly in the areas of the Alps and within the German and French low mountain ranges (Fig. 6a, b). Thus, the patterns seem to reflect the topographic situation throughout the domain. A similar image is drawn for absolute changes (6c) which mostly concentrate on the south western front range of the Alps, the mountain ranges along the Rhine Valley and on smaller spots with elevated terrain.

This explanation does not apply for the patterns of the relative changes in heavy precipitation events (6d). An increase of about $30 \%$ can be found in the northern part of the domain, whereas no significant trend can be observed for the mountainous regions, where small changes carry no 
Fig. 4 Cross section as displayed in Fig. 3, showing the relative change in number of hot days per year. The locations of four major cities are marked with arrows

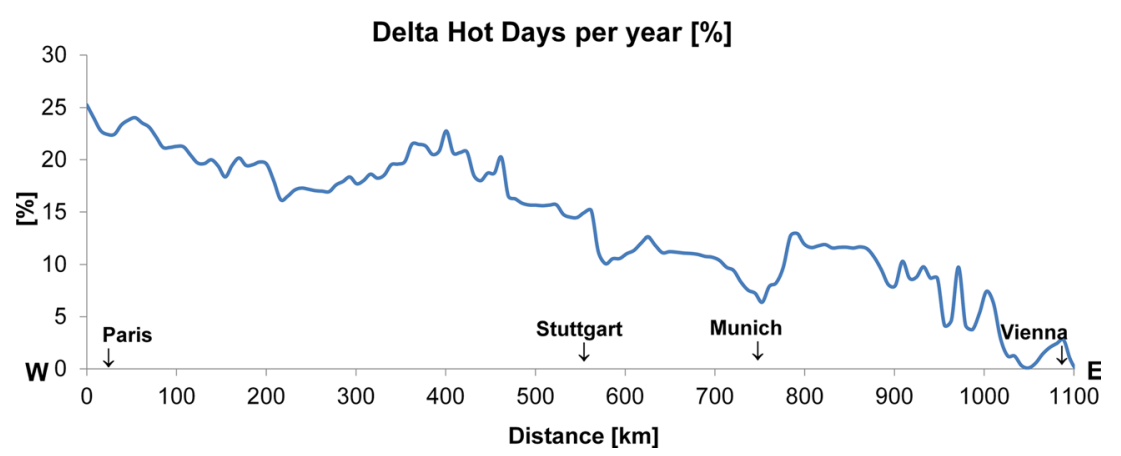

weight. Moreover, a decrease of more than $-10 \%$ is projected for the area around Paris, but due to possible effects at the boundary of the domain, maybe this number has to be corrected. In contrast, the areas of North Germany, Belgium and The Netherlands exhibit a large relative increase of more than $30 \%$. The areas in the west and north-western parts of the domain correspond to the findings of Figs. 3 and 4 showing more hot days and tropical nights in these regions.
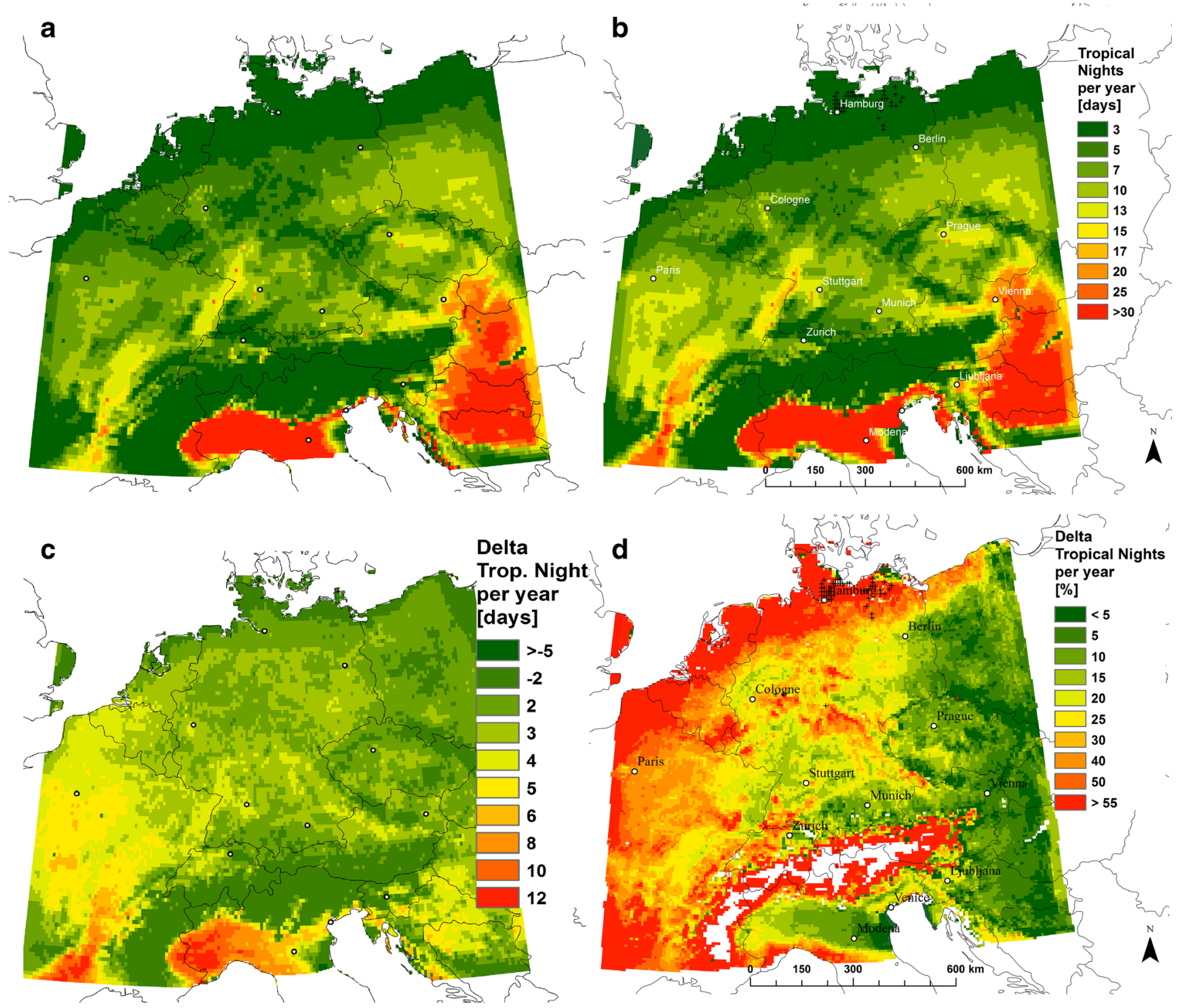

Fig. 5 Yearly average of the number of tropical nights for the past (19712000) (a) and future period 2021-2050 (b). Projected absolute (c) and relative (d) increase in number of tropical nights compared to the

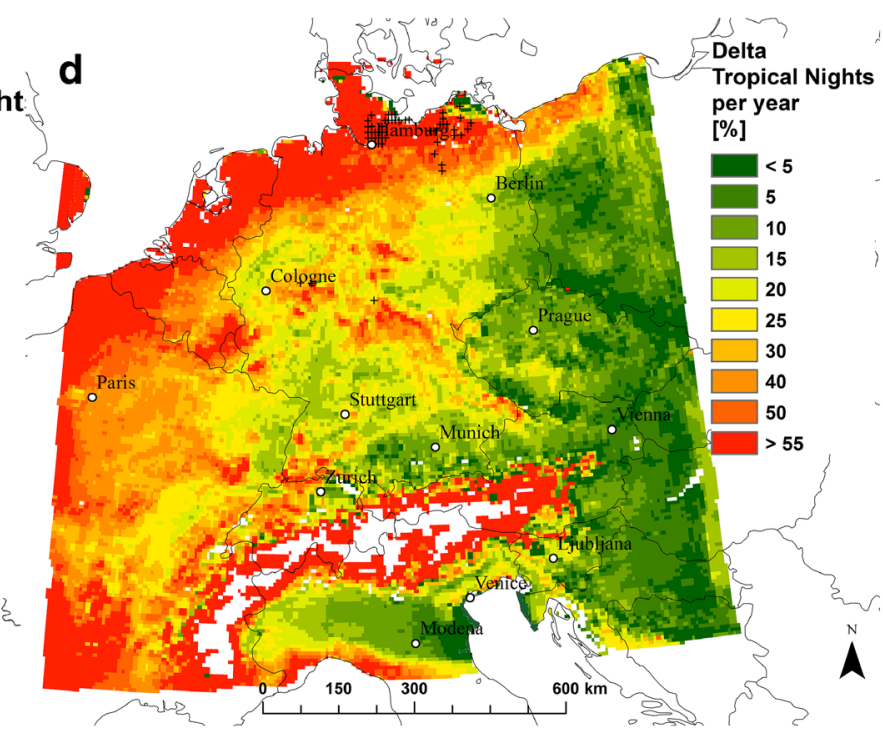

reference period 1971-2000. White shading in the area of the Alps denotes no data values due to division by zero 

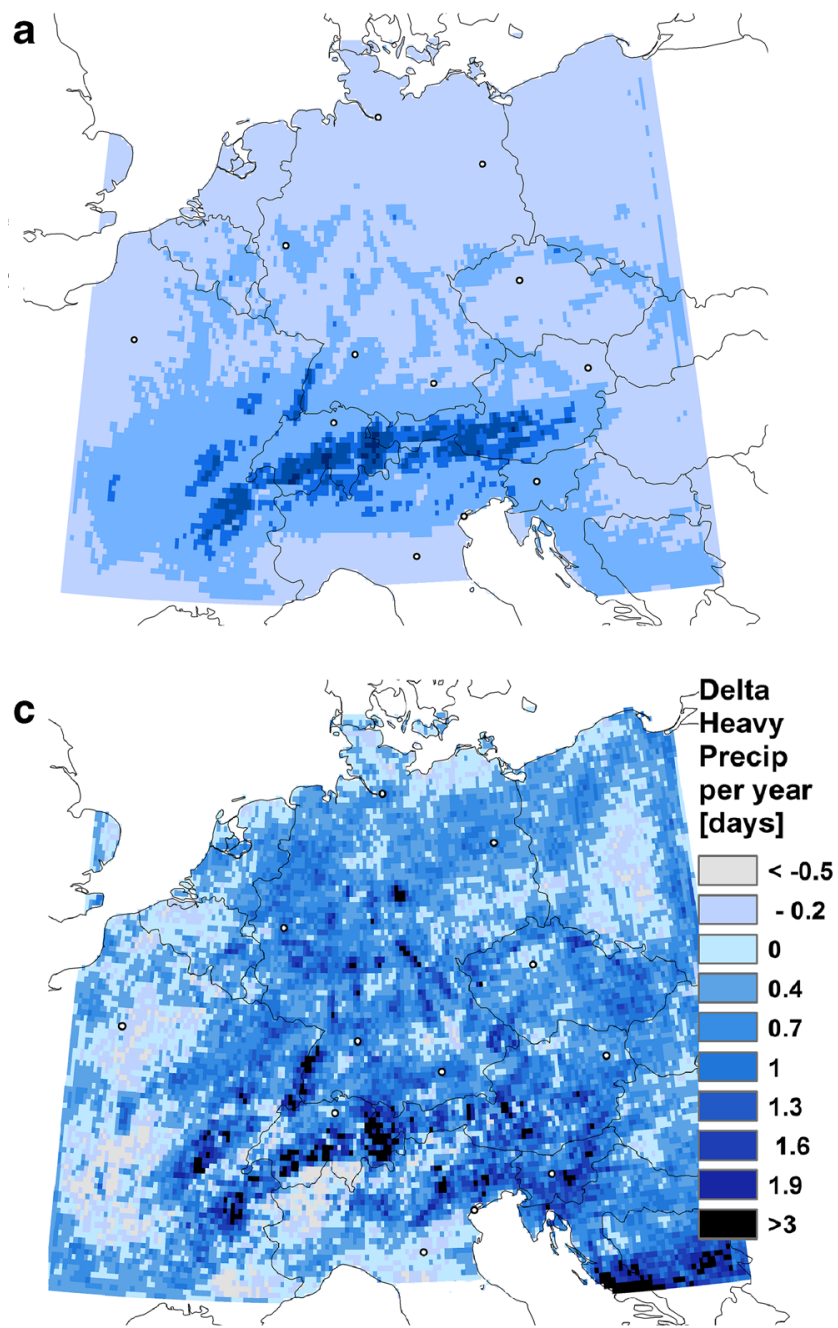

Fig. 6 Projected number of summer days (JJA) in the period 2021-2050, where daily precipitation sum exceeds the threshold of $20 \mathrm{~mm}$ (defined as 'heavy precip'). Absolute values for the period 1971-2000 (a) and for 2021-2050 (b). Dark shading indicates higher values. c shows the

\subsubsection{Frost days}

The number of frost days is displayed in Fig. 7 with absolute values for simulated past (7a) and future periods (7b) with dark colours representing high values. Absolute and relative changes are presented in Fig. 7c, d, respectively. Here, dark colours indicate a slight and light colours a large decrease in number of frost days.

The patterns in Fig. $7 \mathrm{a}, \mathrm{b}$ reflect the topographic situation and the continentality. The number of days with daily minimum temperature falling below $0{ }^{\circ} \mathrm{C}$ is increasing with increasing elevation and distance from the Atlantic Ocean. In general, a decrease of frost days for the period 2021-2050 is projected. Figure $7 \mathrm{c}$, showing absolute changes, indicates the largest decrease occurring in the North Eastern part, with generally more frost days due to winter time atmospheric circulation patterns. Considering relative changes (7d) again reverses

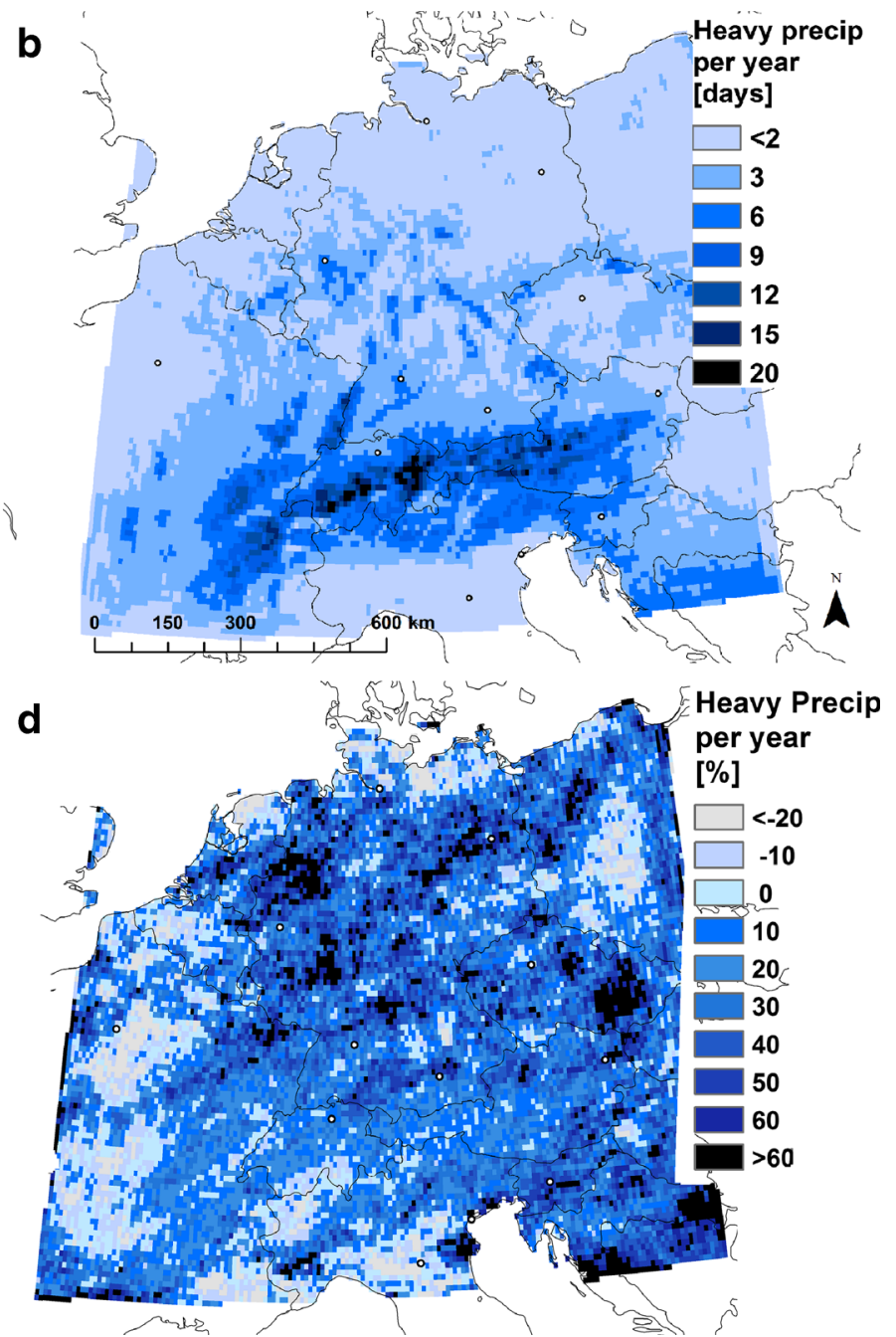

absolute, $\mathbf{d}$ the relative change compared to the reference period 19712000. Here, dark colours represent an increase, grey and white shadings a decrease of days

the image. The biggest climate change impact is projected for the north western part with a projected decrease in number of frost days by up to $45 \%$ at the coastline of the Atlantic Ocean. The negative gradient from the southern border of the Alps up North is illustrated by Fig. 8 .

The peaks at 400 and $550 \mathrm{~km}$ might reflect the Thuringian Forest and the low mountain range of the Harz with a smaller projected decrease in number of frost days. With regard to relative changes, the alpine area can be discriminated significantly because there is no relative trend obvious. A melting of the glaciers due to elevated summertime temperatures and a shortening of the period with snowfall is a more relevant impact of climate change to these regions.

With regard to absolute winter time temperatures, it has to be considered that additional anthropogenic heating has not been accounted for, which might increase winter time temperatures especially in urban areas. 
a

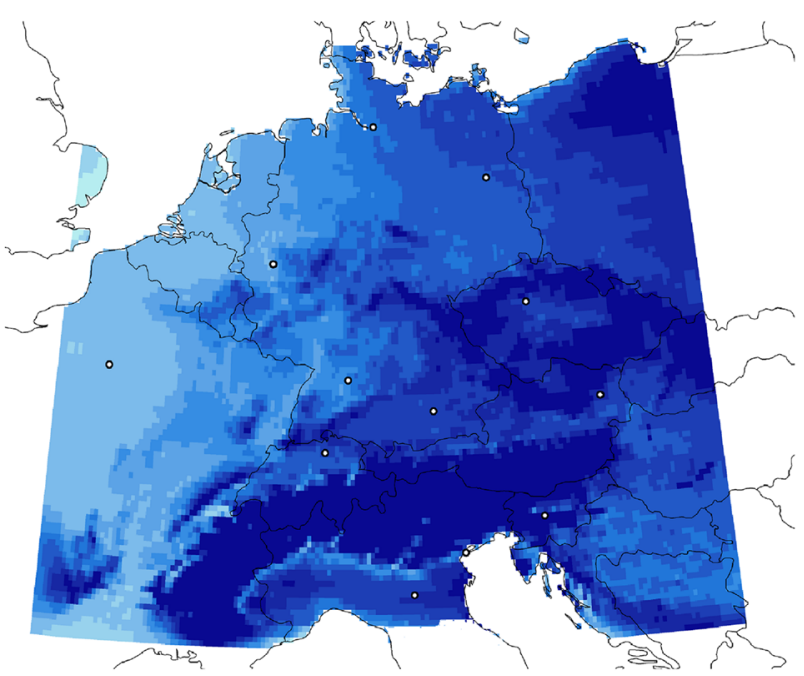

C

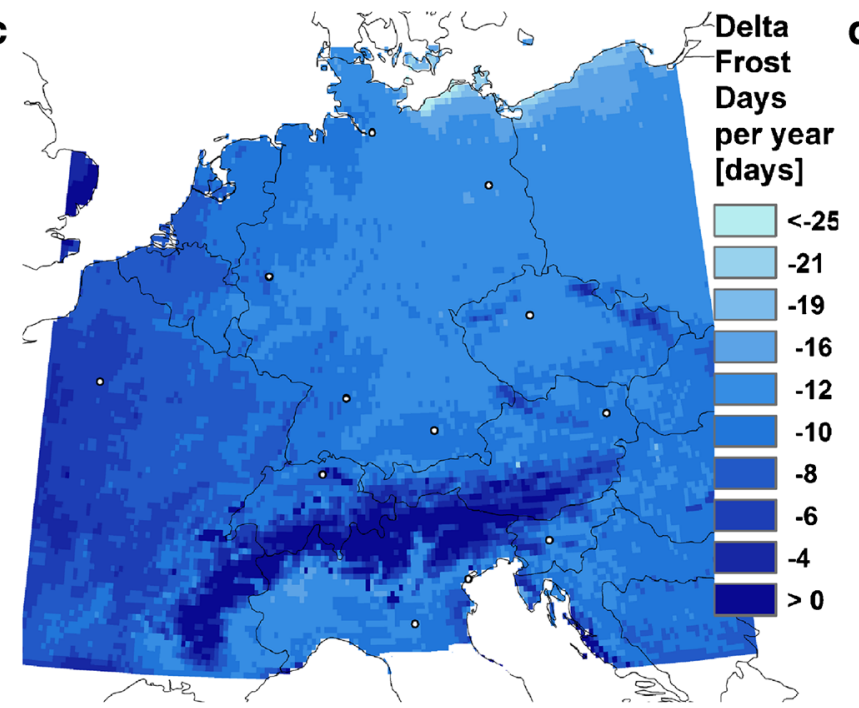

b

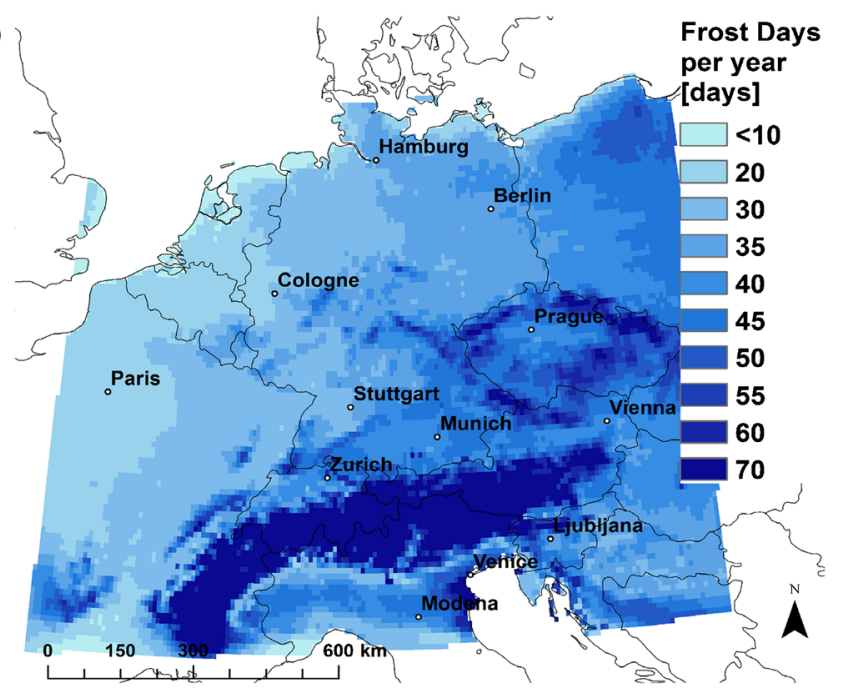

d
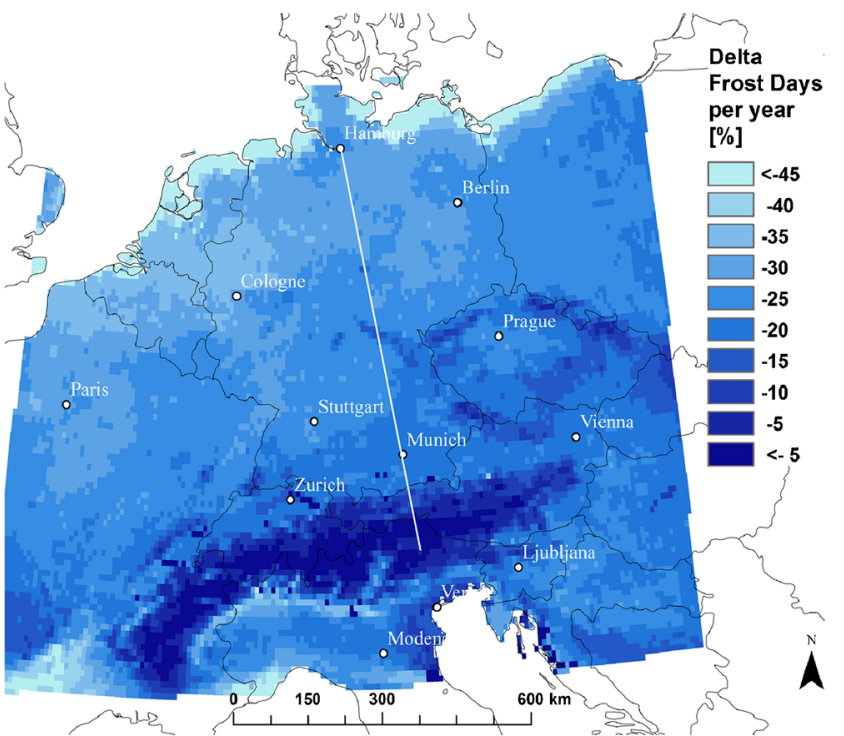

Fig. 7 Yearly average number of frost days for the period 1971-2000 (a) and for the projection 2021-2050 (b). Absolute (c) and relative change (d) compared to the reference period 1971-2000 are shown below. The white line indicates the cross-section presented in Fig. 8

\subsection{Selected urban areas}

\subsubsection{Climate indicators}

Tables 4 and 5 show the climate trends for each selected urban area (grid cells-Figs. 3, 5, 6 and 7). The areas are compared based on absolute values and relative projected changes. The statistical significance on the $95 \%$ confidence interval was tested by applying a student's $t$ test for each calculated relative change presented in Tables 4 and 5. Values which do not fulfil this criterion are in italic type.

The projected number of hot days per year (HD) with temperatures exceeding the predefined threshold of $30^{\circ} \mathrm{C}$ ranges from the maximum of about 38 for the city of Modena and more than 25 with regard to Vienna and Ljubljana. The largest increase is assumed for Hamburg (36\%) and Paris (30\%). For the number of tropical nights $(\mathrm{TN})$, the highest relative increase is projected to be $74 \%$ for Hamburg, whereas the number of heavy precipitation events (HPD) is assumed to rise by over $70 \%$ for Berlin, Paris and Ljubljana. The decrease in the number of frost days (FD) is highest for Cologne, Berlin and Paris (over $40 \%$ ).

In average, the RCM predicts an increase of $12 \%$ for the number of hot days, about $30 \%$ considering tropical nights and a $40 \%$ increase in heavy precipitation events. For the number of frost days, a decrease of $30 \%$ is projected for the period 2021-2050 compared to the reference case 1971-2000 (Table 4).

The number of HDD and CDD for 11 selected urban areas is presented in Table 5. Similar than for the spatial analysis, the relative increase of CDD is more pronounced than a comparable decrease in HDD. With $28 \%$, the urban area of Paris shows the largest relative increase of potential CDD whereas the grid cell representing Prague is supposed to only 
Fig. 8 South-North transect following the white line presented in Fig. $7 \mathrm{~d}$, showing the relative decrease in number of frost days from South to North

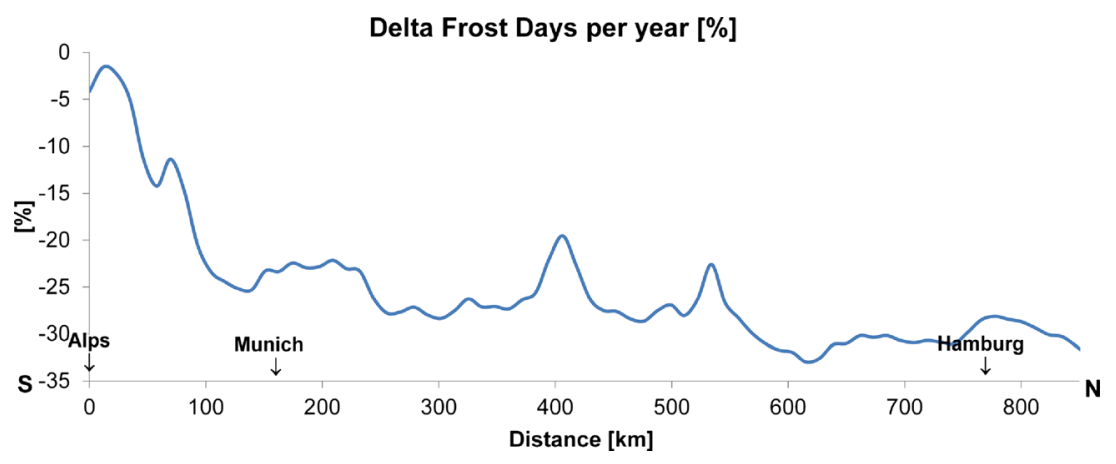

experience $4 \%$ more days with daily mean temperature exceeding $20{ }^{\circ} \mathrm{C}$. With regard to $\mathrm{HDD}$, relative changes range from $-3.7 \%$ (Hamburg) to $-8.1 \%$ (Modena). Averaged over the 11 urban areas, a relative increase of $12 \%$ CDD and decrease of $-5.8 \%$ HDD is projected. The urban areas of Ljubljana and Munich show the highest positive temperature bias (over $1.5^{\circ} \mathrm{C}$ ). This effect potentially leads to a misinterpretation of calculated threshold values.

\subsubsection{Number of heat waves}

With regard to human health, in particular, the number of consecutive 'hot days' has to be distinguished. For this reason, the projected number of heat waves is estimated for the 11 cities under investigation and compared with the reference period. According to the definition given in Chapter 2, different classes of heat waves have been listed in Table 6 .

The characteristics differ from city to city. For moderate heat waves, the urban areas of Berlin and Modena show the highest relative increase with up to $100 \%$, whereas the highest number of moderate heat waves per year is projected for
Vienna (13\% increase). With regard to the strong heat waves, Paris and Zurich show the biggest increase in comparison to the reference case. Although with low annual averages, every city is supposed to encounter heat waves with more than 10 days in the middle of the 21 st century. And in some cities like Hamburg and Berlin, such severe heat waves have not been observed at all within the reference case. The total number of heat waves is presented in the right part of Table 6 and in Fig. 9.

The total number of heat waves per year is increasing for every city, excepted for Vienna and Prague with a projected decrease of 6.4 and $12 \%$, respectively. This is due to the fact that the existence of a heat wave is highly sensitive to threshold values. If, like in the case of Vienna and Prague, this threshold is only undercut by about $0.2{ }^{\circ} \mathrm{C}$, the period is interrupted. If the period is below 5 consecutive days, it is not counted as heat wave. That means, unless the total number of hot days is increasing (Table 5), the number of consecutive hot days can also decrease. Averaged over all 11 cities, an increase from 0.98 to 1.15 heat waves per year (17\%) is projected. According to Figs. 4 and 5, the increase of heat
Table 4 Number of hot days (HD), tropical nights (TN) heavy precipitation days (more than $20 \mathrm{~mm}$ daily sum) (HPD) and frost days (FD) per year for every selected urban area and period 1971-2000 (past) and 2021-2050 (fut). Delta indicates the projected change (\%) comparing the two time periods. Values in italics indicate a failure of the $95 \%$ confidence interval

\begin{tabular}{lcccccccccccc}
\hline City & HD_past & HD_fut & $\begin{array}{l}\text { Delta_HD } \\
(\%)\end{array}$ & TN_past & TN_fut & $\begin{array}{l}\text { Delta_TN } \\
(\%)\end{array}$ & HPD_past & HPD_fut & $\begin{array}{l}\text { Delta_HPD } \\
(\%)\end{array}$ & FD_past & FD_past Delta_FD \\
$(\%)$
\end{tabular}


Table 5 Absolute number of cooling degree days (CDD) and heating degree days (HDD) per year for the period 1971-2000 (past) and 2021-2050 (fut). Delta indicates the projected change (\%) comparing the two time periods. Values in italics indicate a failure of the $95 \%$ confidence interval

\begin{tabular}{llccccc}
\hline City & CDD_past & CDD_fut & Delta_CDD (\%) & HDD_past & HDD_fut & Delta_HDD (\%) \\
\hline Zurich & 56.5 & 62.7 & 11.0 & 243.0 & 228.1 & -6.1 \\
Cologne & 48.2 & 54.6 & 13.3 & 236.4 & 223.7 & -5.4 \\
Hamburg & 24.0 & 27.8 & 16.1 & 281.7 & 271.4 & -3.7 \\
Berlin & 47.4 & 51.5 & 8.6 & 245.0 & 233.7 & -4.6 \\
Paris & 46.2 & 59.3 & 28.3 & 234.4 & 217.1 & -7.4 \\
Stuttgart & 52.3 & 58.1 & 11.0 & 241.9 & 228.0 & -5.8 \\
Modena & 90.7 & 104.3 & 15.1 & 213.7 & 196.4 & -8.1 \\
Prague & 51.6 & 53.7 & 4.1 & 249.1 & 236.0 & -5.3 \\
Vienna & 87.5 & 95.7 & 9.4 & 212.3 & 200.0 & -5.8 \\
Ljubljana & 74.7 & 82.3 & 10.1 & 227.4 & 212.5 & -6.6 \\
Munich & 54.5 & 59.6 & 9.5 & 248.5 & 234.7 & -5.6 \\
Mean & 57.6 & 64.5 & 12.4 & 239.4 & 225.6 & -5.8 \\
\hline
\end{tabular}

waves in the western part is higher than in the eastern part. Due to a mean temperature bias of over $1.5^{\circ} \mathrm{C}$, the results for the urban areas of Munich and Ljubljana are not very robust.

\subsubsection{Probability density functions}

Monthly mean temperatures are extracted for one grid cell in the centre of a selected urban region to create probability density functions in order to statistically compare the modelling results. By calculating the values to fall below the $5 \%$ confidence interval, the tendency towards extreme trends is to be analysed on the basis of the comparison of the future (20212050) with the reference period (1971-2000). Probability density functions (PDF) of mean daily temperatures for six selected urban grid cells, representing urban areas in each cardinal direction and in the centre of the domain, are presented in Fig. 10, whereas a statistical summary is given in Table 7 .

Although the appearance of the PDF of monthly mean temperature in the case of Vienna does not change significantly, a clear shift in the 95 th percentile of about $1.4{ }^{\circ} \mathrm{C}$ is obvious. With regard to Munich, the red curve (future) tends to be flattened compared with the blue curve and shows a similar increase in the 95th percentile. Modena shows two similar curves but with a shift in mean and maximum values from 27 to $30.6{ }^{\circ} \mathrm{C}$ considering monthly summer mean temperatures. The three plots illustrated in the lower part of Fig. 10 show a distinct compression of the future curve, indicating a broader range of values in the future. This effect is largest for the city of Paris. Here, the 95th percentile strongly reflects a climate signal, with an increase of $2{ }^{\circ} \mathrm{C}$. The statistical description of the PDF's for all 11 cities is shown in Table 7 on the basis of absolute changes in mean, maximum and minimum temperature, as well as in the median.

The strongest increase of the 95th percentile is projected for Hamburg with $3{ }^{\circ} \mathrm{C}$ and Berlin and Paris with almost $2{ }^{\circ} \mathrm{C}$ each. Maximum temperatures are forecasted to increase by up to $4{ }^{\circ} \mathrm{C}$ for Munich, Stuttgart and Zurich, Ljubljana and Modena and even $4.5^{\circ} \mathrm{C}$ for Paris. The changes in mean, median and minimum are marginal compared to the increase in maximum temperatures.
Table 6 Number of periods per year, where the threshold temperature of $30^{\circ} \mathrm{C}$ is exceeded on a certain number of consecutive days (5-6 days, 7 9 days, 10 days and more) with regard to the specific city. On the right side of the plot, the yearly averaged sum of all heat waves which last at least 5 days is counted

\begin{tabular}{|c|c|c|c|c|c|c|c|c|}
\hline & \multicolumn{2}{|c|}{ 'Moderate' (5-6 days) } & \multicolumn{2}{|c|}{ 'Strong' (7-9 days) } & \multicolumn{2}{|c|}{ 'Severe’ ( $\geq 10$ days) } & \multicolumn{2}{|c|}{ Total ( $\geq 5$ days) } \\
\hline & Reference & Future & Reference & Future & Reference & Future & Reference & Future \\
\hline Zurich & 0.57 & 0.52 & 0.13 & 0.22 & 0.17 & 0.22 & 0.87 & 0.96 \\
\hline Cologne & 0.39 & 0.35 & 0.09 & 0.13 & 0.04 & 0.22 & 0.52 & 0.70 \\
\hline Hamburg & 0.00 & 0.13 & 0.00 & 0.09 & 0.00 & 0.04 & 0.00 & 0.26 \\
\hline Berlin & 0.17 & 0.35 & 0.09 & 0.09 & 00.0 & 0.09 & 0.26 & 0.52 \\
\hline Paris & 0.26 & 0.43 & 0.04 & 0.35 & 0.13 & 0.09 & 0.43 & 0.87 \\
\hline Stuttgart & 0.48 & 0.70 & 0.17 & 0.09 & 0.13 & 0.22 & 0.78 & 1.00 \\
\hline Modena & 0.57 & 1.04 & 0.65 & 0.83 & 1.04 & 1.00 & 2.26 & 2.87 \\
\hline Prague & 0.61 & 0.43 & 0.09 & 0.09 & 0.04 & 0.13 & 0.74 & 0.65 \\
\hline Vienna & 1.00 & 1.13 & 0.65 & 0.48 & 0.39 & 0.30 & 2.04 & 1.91 \\
\hline Ljubljana & 0.78 & 1.09 & 0.87 & 0.61 & 0.43 & 0.52 & 2.09 & 2.22 \\
\hline Munich & 0.35 & 0.52 & 0.26 & 0.09 & 0.13 & 0.13 & 0.74 & 0.74 \\
\hline
\end{tabular}


Fig. 9 Total number of heat waves per year with at least 5 consecutive days for each of the 11 cities considering the reference period (grey) and the future run (black)

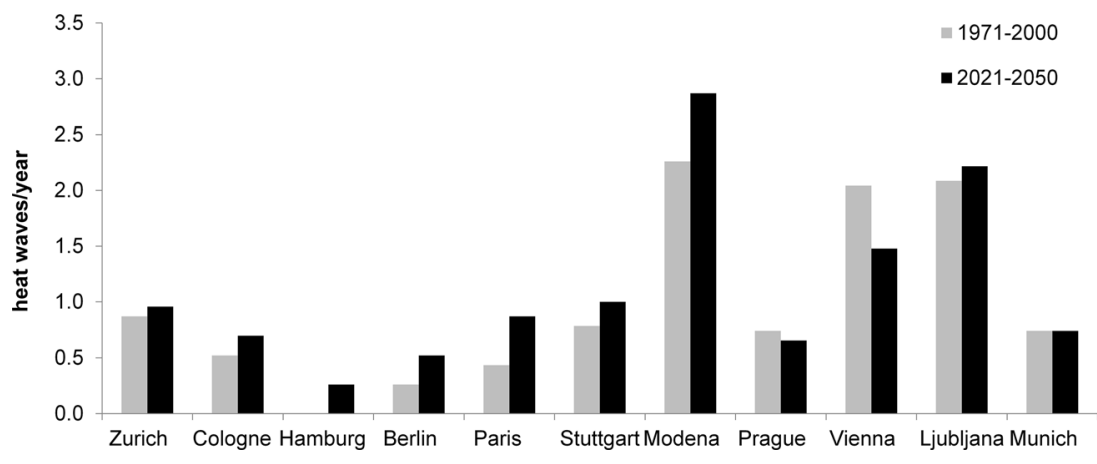

It seems that the projected annual mean temperature change for Germany of about $1{ }^{\circ} \mathrm{C}$, as presented in Wagner et al. (2013), is not reflected by single urban areas, which indicate a mean of $0.49^{\circ} \mathrm{C}$. It seems that the climate change impact regarding mean temperature is less pronounced locally for single urban areas than regionally for the whole German domain.

\section{Conclusion}

Urban areas in Central Europe will react to climate change, according to projections from an existing 7-km RCM run for the near future (2012-2050) compared to the reference period (1971-2000) using the IPCC AR4 A1B Scenario as boundary conditions. The model resolution enables the analysis of climate change impact on selected urban areas in Europe although the complex nature of cities cannot be fully resolved.
In order to support the assessment of the model results, we have added a detailed analysis of the model bias, comparing model results with the E-OBS dataset (Haylock 2008). We observed a cold temperature bias in the region of the Alps and a warm bias in the south-eastern part of the domain. With regard to precipitation, a wet bias over the Alps and a dry bias in the South-East can be found. The biases are partly originated from the GCM and carried over to the RCM and partly amplified or reduced by WRF itself. Overall, the bias of WRF is in the same range than other RCMs (Berg et al. 2013, Jacob et al. 2007). The analysis of the model bias allows a comprehensive evaluation of the simulated climate change signal for the selected urban areas. For certain cities, periods of 5 and more consecutive days with extreme temperatures are projected. At some locations, the number of hot days is to increase by over $70 \%$, relative to the reference period. In average, the number of heat waves is projected to increase by $17 \%$ and the number of tropical nights by $30 \%$.
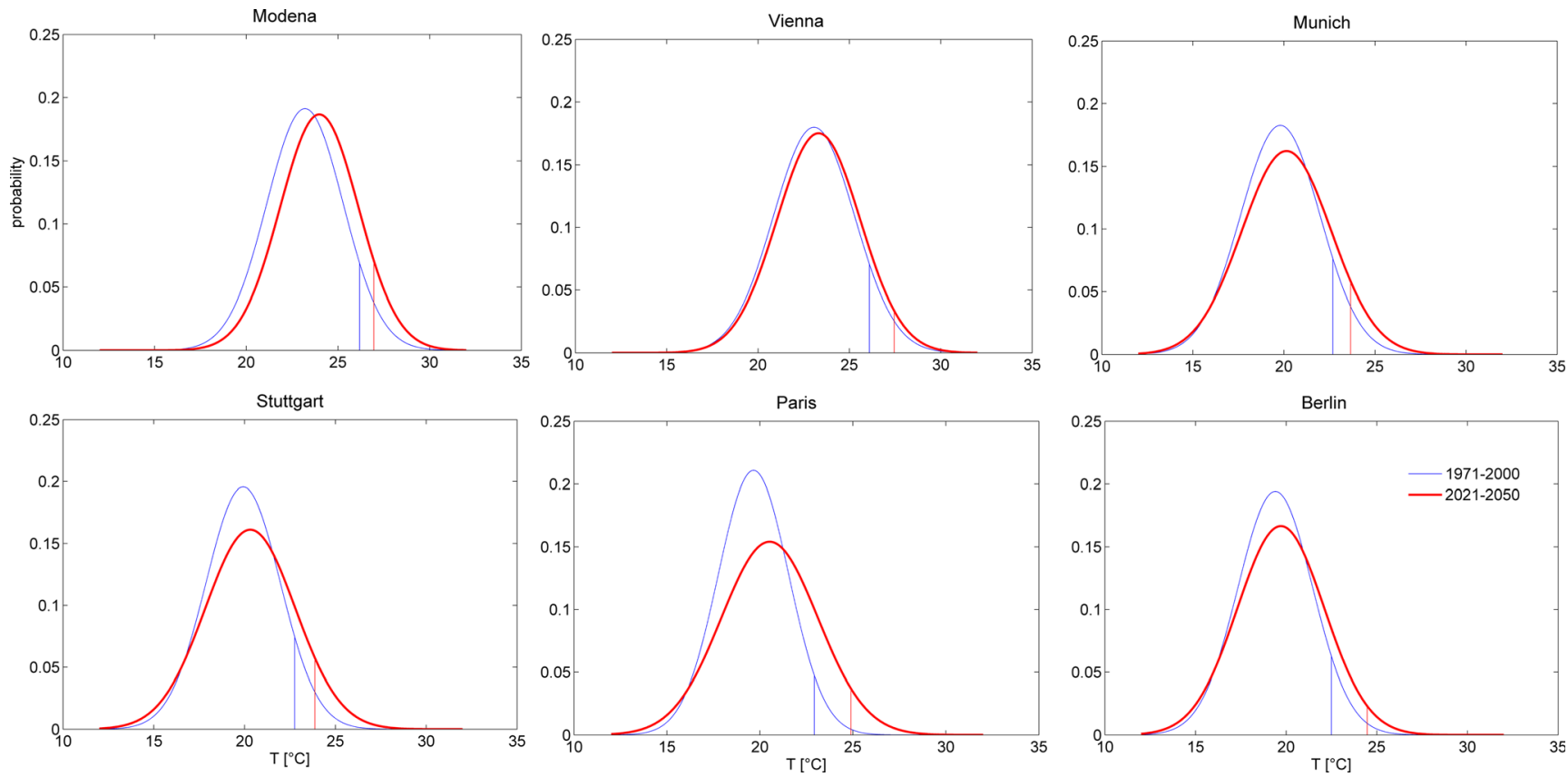

Fig. 10 Probability density functions (PDFs) extracted for the central $7 \times 7-\mathrm{km}$ pixel of a selected urban area. The blue line indicates the probability density curve for extracted monthly mean summer temperatures in the past (1971-2000); the red line shows the same for the future (2021-2050) period. The vertical lines illustrate the 95th percentile for each plot and time frame 
Table 7 Absolute changes in 95th percentile, mean, maximum, minimum and median of monthly mean values of $2-\mathrm{m}$ temperature with regard to the cities, analysed in the PDF plots in Fig. 10

\begin{tabular}{llllll}
\hline City & $95 \mathrm{p}\left({ }^{\circ} \mathrm{C}\right)$ & Mean $\left({ }^{\circ} \mathrm{C}\right)$ & $\operatorname{Max}\left({ }^{\circ} \mathrm{C}\right)$ & $\operatorname{Min}\left({ }^{\circ} \mathrm{C}\right)$ & Median $\left({ }^{\circ} \mathrm{C}\right)$ \\
\hline Berlin & 1.98 & 0.31 & 1.55 & 1.48 & 0.27 \\
Paris & 1.97 & 0.87 & 4.48 & -0.86 & 0.81 \\
Vienna & 1.36 & 0.25 & 2.51 & 1.41 & 0.28 \\
Hamburg & 3.02 & 0.62 & 2.92 & 1.75 & 0.38 \\
Munich & 0.97 & 0.34 & 3.98 & 0.32 & 0.17 \\
Prague & 1.09 & 0.18 & 1.95 & 1.22 & 0.17 \\
Cologne & 1.31 & 0.55 & 2.87 & 0.16 & 0.29 \\
Stuttgart & 1.11 & 0.39 & 3.78 & -0.33 & 0.20 \\
Zurich & 0.73 & 0.46 & 4.24 & -0.55 & 0.65 \\
Ljubljana & 0.92 & 0.40 & 3.55 & 0.57 & 0.30 \\
Modena & 0.77 & 0.78 & 3.68 & 0.64 & 0.59 \\
\hline
\end{tabular}

In average, the number of frost days is projected to decrease by $26 \%$ considering the European domain. The accompanied decrease of HDDs has the potential to save energy needed for heating of the buildings in winter time. This study, however, shows that the relative increase in cooling degree days will preponderance the relative decrease of heating degree days.

From an energetic point of view, a higher CCD number accounts for an increased need for electrical power to operate air conditioning systems, inferring an increase in energy consumption. This effect is highly pronounced in urban areas with generally elevated temperatures compared to the rural surrounding (Oke, 1982b). Not only temperature but also precipitation events have to be taken into account when dealing with urban environments, especially for cities located nearby riverbeds, already endangered from flooding during heavy precipitation events. Model results reveal a moderate increase in heavy precipitation events, with a higher tendency towards the North. Other meteorological parameters like wind speed, humidity and shortwave radiation were also extracted from the reference and the future WRF RCM runs, but no significant tendency was found here. The evolution of probability density functions for monthly mean temperatures reflects the tendency for a shift to higher temperatures in the future for every selected city, which again is an indicator for an intensification of extreme events like heat waves. In average, the 95 th percentile is projected to increase by $1.4{ }^{\circ} \mathrm{C}$.

This study shows additional evidence that regional climate models like WRF can help to understand how global climate change will be pronounced on regional scales. The output from these kinds of models can in turn be used as boundary condition for high resolution city or even street scale models which can help to locally predict climate change impacts in order to strengthen the resilience of future cities.

Our study benefits from a combined analysis of climate change impacts on urban areas in comparison to the overall projected changes for Europe. Consistent climate boundary conditions are driving the RCM, which allows for the analysis of several urban areas within one modelling approach. Addressing different climate indicators and their interrelation, the study aims to increase the understanding of expected climate change effects on urbanized areas and urban dwellers. For future studies, it is aimed to further increase the model resolution and incorporate specific urban canopy parameterizations (Kusaka et al. 2001; Martilli et al. 2002) within the framework.

Acknowledgments The RCM simulations were performed within the CEDIM-project "Flood hazard in a changing climate" (Schaedler et al. 2012) and carried out at HLRS at the University of Stuttgart.

Part of this work is funded by the EU Project "UHI - Development and application of mitigation and adaptation strategies and measures for counteracting the global UHI phenomenon" (3CE292P3) - Central Europe (2011-2014). Further acknowledgement should be given to the Project: Synthetic precipitation time series for the optimal design and operation of urban drainage systems (SYNOPSE) funded by the BMBF within the programme INIS - Intelligent and multi-functional infrastructure systems for a sustainable water supply and wastewater disposal.

Open Access This article is distributed under the terms of the Creative Commons Attribution 4.0 International License (http:// creativecommons.org/licenses/by/4.0/), which permits unrestricted use, distribution, and reproduction in any medium, provided you give appropriate credit to the original author(s) and the source, provide a link to the Creative Commons license, and indicate if changes were made.

\section{References}

Beniston M (2004) The 2003 heat wave in Europe: a shape of things to come? An analysis based on Swiss climatological data and model simulations. Geophys Res Lett 31(2):L02202. doi:10.1029/ 2003GL018857

Beniston M, Stephenson D, Christensen O, Ferro C, Frei C, Goyette Sp, Halsnaes K, Holt T, Jylhoenen K, Koffi B, Palutikof J, Schoell R, Semmler T, Woth K (2007) Future extreme events in European climate: an exploration of regional climate model projections. Clim Chang 81(1):71-95. doi:10.1007/s10584-006-9226-z

Beniston M (2009) Trends in joint quantiles of temperature and precipitation in Europe since 1901 and projected for 2100. Geophys Res Lett 36(7)

Berg P, Wagner S, Kunstmann H, Schaedler G (2013) High resolution regional climate model simulations for Germany: part I-validation. Clim Dyn 40(1-2):401-414. doi:10.1007/s00382-012-1508-8

Boberg F, Berg P, Thejll P, Gutowski W, Christensen J (2010) Improved confidence in climate change projections of precipitation further evaluated using daily statistics from ENSEMBLES models. Clim Dyn 35(7-8):1509-1520. doi:10.1007/s00382-009-0683-8

Borge R, Alexandrov V, José del Vas J, Lumbreras J, Rodríguez E (2008) A comprehensive sensitivity analysis of the WRF model for air quality applications over the Iberian Peninsula. Atmos Environ 42(37):8560-8574 available from: http://www.sciencedirect.com/ science/article/pii/S1352231008007954

Brinkhoff, T. City Population. 2013. Ref Type: Online Source: http:// www.citypopulation.de/, 05/15/2014.

Chen F, Dudhia J (2001) Coupling an advanced land-surface hydrology model with the PennState NCAR MM5 modeling system. Part I: 
model description and implementation. Mon Weather Rev 129:569585

Christensen J, Christensen OS (2007) A summary of the PRUDENCE model projections of changes in European climate by the end of this century. Clim Chang 81(1):7-30. doi:10.1007/s10584-006-9210-7

Della-Marta PM, Haylock MR, Luterbacher J, Wanner H (2007) Doubled length of western European summer heat waves since 1880. J Geophys Res-Atmos 112(D15):D15103. doi:10.1029/ 2007JD008510

Dudhia J (1989) Numerical study of convection observed during the winter monsoon experiment using a mesoscale two-dimensional model. J Atmos Sci 46:3077-3107

Erhardt RJ (2015) Mid-twenty-first-century projected trends in North American heating and cooling degree days. Environmetrics 26(2): 133-144. doi:10.1002/env.2318

Kain JS (2004) The Kain-Fritsch convective parameterization: an update. J Appl Meteor 43:170-181

Feldmann HB, Schaedler G, Panitz HJ, Keuler K, Jacob D, Lorenz P (2008) Evaluation of the precipitation for South-western Germany from high resolution simulations with regional climate models. Meteorologische Zeitschrift 17(4):455-465 1-8-2008

Frei C, Schär C (2001) Detection probability of trends in rare events: theory and application to heavy precipitation in the Alpine region. J Clim 14(7):1568-1584. doi:10.1175/1520-0442(2001) 014<1568:DPOTIR>20CO;2 Accessed 28 May 2015.

Frich P, Alexander LV, Della-Marta P, Gleason B, Haylock M, Klein Tank AM, Peterson T (2002) Observed coherent changes in climatic extremes during the second half of the twentieth century. Clim Res 19(3):193-212

Grimm NB, Faeth SH, Golubiewski NE, Redman CL, Wu J, Bai X, Briggs JM (2008) Global change and the ecology of cities. Science 319(5864):756-760 available from: http://www. sciencemag.org/content/319/5864/756.abstract

Haylock MR, Cawley GC, Harpham C, Wilby RL, Goodess CM (2006) Downscaling heavy precipitation over the United Kingdom: a comparison of dynamical and statistical methods and their future scenarios. Int J Climatol 26(10):1397-1415. doi:10.1002/joc.1318

Haylock M, Hofstra N, Klein Tank AMG, Klok EJ, Jones PD, New M (2008) A European daily high-resolution gridded dataset of surface temperature, precipitation and sea-level pressure. J Geophys Res 113:D20119. doi:10.1029/2008JD010201

Hewitt CD (2004) Ensembles-based predictions of climate changes and their impacts. Eos, Trans AGU 85(52):566. doi:10.1029/ 2004EO520005

Hofstra N, New M, McSweeney C (2010) The influence of interpolation and station network density on the distributions and trends of climate variables in gridded daily data. Clim Dyn 35(5):841-858. doi: 10.1007/s00382-009-0698-1

Hong SY, Lim JOJ (2006) The WRF single-moment 6-class microphysics scheme (WSM6). J Korean Meteor Soc 42:129-151

Hong SY, Dudhia J, Chen SH (2004) A revised approach to ice microphysical processes for the bulk parameterization of clouds and precipitation. Mon Weather Rev 132:103-120

Hong SY, Noh Y, Dudhia J (2006) A new vertical diffusion package with an explicit treatment of entrainment processes. Mon Weather Rev $134: 2318-2341$

IPCC, 2013 Summary for policymakers. In: Climate change 2013: The physical science basis. Contribution of working group I to the fifth assessment report of the intergovernmental panel on climate change [Stocker, T.F., D. Qin, G.-K. Plattner, M. Tignor, S.K. Allen, J. Boschung, A. Nauels, Y. Xia, V. Bex and P.M. Midgley (eds.)]. Cambridge University Press, Cambridge, United Kingdom and New York, NY, USA

Jacob D, Bärring L, Christensen O, Christensen J, Castro M, Deque M, Giorgi F, Hagemann S, Hirschi M, Jones R, Kjellström E, Lenderink G, Rockel B, Sanchez E, Schär C, Seneviratne S, Somot S, Ulden A,
Hurk B (2007) An inter-comparison of regional climate models for Europe: model performance in present-day climate. Clim Chang 81(1):31-52. doi:10.1007/s10584-006-9213-4

Kusaka H, Kondo H, Kikegawa Y, Kimura F (2001) A simple singlelayer urban canopy model for atmospheric models: comparison with multi-layer and slab models. Bound-Layer Meteorol 101(3):329 358. doi:10.1023/A\%3A1019207923078

Liu Y, Chen F, Warner T, Basara J (2006) Verification of a mesoscale data-assimilation and forecasting system for the Oklahoma City area during the Joint Urban 2003 field project. J Appl Meteorol Climatol 45(7):912-929. doi:10.1175/JAM2383.1 Accessed 4 June 2013

Martilli A, Clappier A, Rotach M (2002) An urban surface exchange parameterisation for mesoscale models. Bound-Layer Meteorol 104(2):261-304. doi:10.1023/A\%3A1016099921195

Meehl GA, Tebaldi C (2004) More intense, more frequent, and longer lasting heat waves in the 21st century. Science 305(5686):994-997 available from: http://www.sciencemag.org/content/305/5686/994. abstract

Mlawer EJ, Taubman SJ, Brown PD, Iacono MJ, Clough SA (1997) Radiative transfer for inhomogeneous atmosphere: RRTM, a validated correlated-k model for the longwave. J Geophys Res 102: 16663-16682

Mueller, R. \& Schulzweida, U. 2010 Climate data operators. Version 1[5.1], 614. Ref Type: Online Source: http://vista.cira.colostate. edu/nco/documents/CDO/cdo.pdf, 05/15/2014

Oke TR (1982b) The energetic basis of the urban heat island. Q J R Meteorol Soc 108(455):1-24. doi:10.1002/qj.49710845502

OrtizBevia, M.J., Sanchez-Lopez, G., Alvarez-Garcia, F.J., \& RuizdeElvira, A. 2012. Evolution of heating and cooling degreedays in Spain: trends and interannual variability. Global Planet Chang, 92 Çô9, (0) 236-247 available from: http://www. sciencedirect.com/science/article/pii/S0921818112001075

Poumadere M, Mays C, Le Mer S, Blong R (2005) The 2003 heat wave in France: dangerous climate change here and now. Risk Anal 25(6): 1483-1494. doi:10.1111/j.1539-6924.2005.00694.x

Robine JM, Cheung SL, Le Roy S, Van Oyen H, Griffiths C, Michel JP, Herrmann FR (2008) Death toll exceeded 70,000 in Europe during the summer of 2003. Comptes Rendus Biologies 331(2):171-178 available from: http://www.sciencedirect.com/science/article/pii/ S1631069107003770

Roeckner G, Baeuml G, Bonaventura L, Brokopf R, Esch M, Giorgetta M, Hagemann S, Kirchner I, Kornblueh L, Manzini E, Rhodin A, Schlese U, Schulzweida U, Tompkins A (2003) The atmospheric general circulation model ECHAM 5. PART I: model description. Technical report, MPImet/MAD Germany

Salathe E, Leung LR, Qian Y, Zhang Y (2010) Regional climate model projections for the State of Washington. Clim Chang 102(1-2):5175. doi:10.1007/s10584-010-9849-y

Skamarock W, Klemp J, Dudhia J, Gill D, Barker D, Duda M, Huang X, Wang W, Powers J (2008) A description of the advanced research WRF version 3. NCAR technical note 475. National Center for Atmospheric Research, Boulder

Schaedler, G., Berg, P., Duethmann, D., Feldmann, H., Ihringer, J., Kunstmann, H., Liebert, J., Merz, B., Ott, I., \& Wagner, S. 2012, Flood hazard in a changing climate, Tech. rep., CEDIM report Karlsruhe, Germany. http://www. cedim. de/download/ Flood Hazards in a Changing Climate. pdf.

Schwitalla T, Bauer H. H, Wulfmeyer V, Aoshima F (2011) Highresolution simulation over central Europe: assimilation experiments during COPS IOP 9c. Q J R Meteorol Soc 137(S1):156-175. doi:10. 1002/qj.721

Shepherd JM (2005) A review of current investigations of urban-induced rainfall and recommendations for the future. Earth Interactions 9(12):1-27. doi:10.1175/EI156.1 Accessed 8 June 2015

Solomon, S. et al. Contribution of working group I to the fourth assessment report of the intergovernmental panel on climate change, 2007. 
2007. Cambridge University Press, Cambridge, United Kingdom and New York, NY, USA. 23-5-2013. Ref Type: Online Source: http://www.ipcc.ch/publications_and_data/ar4/wg1/en/contents. html, 05/15/2014

Stone Jr, B. 2012. The city and the coming climate: climate change in the places we live Cambridge University Press.

Tinz, B., Freydank, E., \& Hupfer, P. 2008. Hitzeepisoden in Deutschland im 20. und 21. Jahrhundert. Warnsignal Klima: Gesundheitsrisiken.Gefahren fuer Menschen, Tiere und Pflanzen, Hamburg 141-148

Trusilova K, Jung M, Churkina G, Karstens U, Heimann M, Claussen M (2008) Urbanization impacts on the climate in Europe: numerical experiments by the PSUG NCAR mesoscale model (MM5). Journal of Applied Meteorology \& Climatology 47(5)

United Nations 2011 Urban population, development and environment. Ref Type: Online Source:http:/www.un.org/esa/population/ publications/2011UrbanPopDevEnv_Chart/urban_wallchart 2011web-smaller.pdf, 05/15/2014

USGS 2006 USGS Land Cover Classification. Ref Type: Online Source: http://landcover.usgs.gov/usgslandcover.php, 02/04/2014.

Wagner S, Berg P, Schaedler G, Kunstmann H (2013) High resolution regional climate model simulations for Germany: part II - projected climate changes. Clim Dyn 40(1-2):415-427. doi:10.1007/s00382012-1510-1 